\title{
Methylglyoxal Produced by Amyloid- $\beta$ Peptide-Induced Nitrotyrosination of Triosephosphate Isomerase Triggers Neuronal Death in Alzheimer's Disease
}

\author{
Marta Tajes $^{\mathrm{a}}$, Abel Eraso-Pichot ${ }^{\mathrm{a}}$, Fanny Rubio-Moscardóa ${ }^{\mathrm{a}}$, Biuse Guivernau ${ }^{\mathrm{a}}$, Eva Ramos-Fernández ${ }^{\mathrm{a}}$, \\ Mònica Bosch-Morató ${ }^{\mathrm{a}}$, Francesc Xavier Guix ${ }^{\mathrm{a}}$, Jordi Clarimón ${ }^{\mathrm{b}}$, Gian Pietro Miscione ${ }^{\mathrm{c}, \mathrm{d}}$, \\ Mercé Boada $^{\mathrm{e}, \mathrm{f}}$, Gabriel Gil-Gómez ${ }^{\mathrm{g}}$, Toshiharu Suzuki ${ }^{\mathrm{h}}$, Henrik Molina ${ }^{\mathrm{i}}$, Jordi Villà-Freixa ${ }^{\mathrm{c}, \mathrm{j}}$, \\ Rubén Vicente ${ }^{\mathrm{a}}$ and Francisco J. Muñoz ${ }^{\mathrm{a}, *}$ \\ ${ }^{\mathrm{a}}$ Laboratory of Molecular Physiology and Channelopathies, Departament de Ciències Experimentals i de la Salut \\ (DCEXS), Universitat Pompeu Fabra (UPF), Barcelona, Spain \\ ${ }^{\mathrm{b}}$ Alzheimer Laboratory, Neurology Department, Hospital de la Santa Creu i Sant Pau, Barcelona, Centro de \\ Investigación Biomédica en Red sobre Enfermedades Neurodegenerativas (CIBERNED), Spain \\ ${ }^{\mathrm{c} C o m p u t a t i o n a l ~ B i o c h e m i s t r y ~ a n d ~ B i o p h y s i c s ~ L a b o r a t o r y, ~ R e s e a r c h ~ P r o g r a m ~ o n ~ B i o m e d i c a l ~ I n f o r m a t i c s, ~ D C E X S, ~}$ \\ IMIM/UPF, Barcelona, Spain \\ ${ }^{\mathrm{d}}$ Dipartimento di Chimica "G. Ciamician”, Universitá degli Studi di Bologna, Italy \\ ${ }^{\mathrm{e}}$ Memory Clinic, Fundació ACE. Institut Català de Neurociències Aplicades, Barcelona, Spain \\ ${ }^{\mathrm{f}}$ Neurology Department, Hospital Universitari Vall d'Hebron-Institut de Recerca, Universitat Autònoma de \\ Barcelona (VHIR-UAB), Barcelona, Spain \\ gIMIM (Institut Hospital del Mar d'Investigacions Mèdiques), Barcelona, Spain \\ ${ }^{\mathrm{h}}$ Laboratory of Neuroscience, Graduate School of Pharmaceutical Sciences, Hokkaido University, Sapporo, Japan

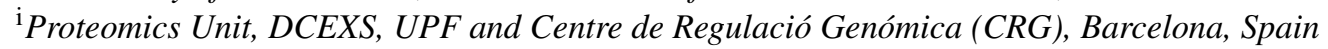 \\ ${ }^{\mathrm{j}}$ Escola Politécnica Superior, Universitat de Vic, Spain
}

Accepted 21 January 2014

\begin{abstract}
Amyloid- $\beta$ peptide $(\mathrm{A} \beta)$ aggregates induce nitro-oxidative stress, contributing to the characteristic neurodegeneration found in Alzheimer's disease (AD). One of the most strongly nitrotyrosinated proteins in AD is the triosephosphate isomerase (TPI) enzyme which regulates glycolytic flow, and its efficiency decreased when it is nitrotyrosinated. The main aims of this study were to analyze the impact of TPI nitrotyrosination on cell viability and to identify the mechanism behind this effect. In human neuroblastoma cells (SH-SY5Y), we evaluated the effects of $\mathrm{A} \beta_{42}$ oligomers on TPI nitrotyrosination. We found an increased production of methylglyoxal (MG), a toxic byproduct of the inefficient nitro-TPI function. The proapoptotic effects of $\mathrm{A} \beta_{42}$ oligomers, such as decreasing the protective Bcl2 and increasing the proapoptotic caspase- 3 and Bax, were prevented with a MG chelator. Moreover, we used a double mutant TPI (Y165F and Y209F) to mimic nitrosative modifications due to A $\beta$ action. Neuroblastoma cells transfected with the double mutant TPI consistently triggered MG production and a decrease in cell viability due to apoptotic mechanisms. Our data show for the first time that MG is playing a key role in the neuronal death induced by A $\beta$ oligomers. This occurs because of TPI nitrotyrosination, which affects both tyrosines associated with the catalytic center.
\end{abstract}

Keywords: Alzheimer's disease, amyloid, apoptosis, methylglyoxal, 3-nitrotyrosine, triose-phosphate isomerase

\footnotetext{
${ }^{*}$ Correspondence to: Dr. Francisco J. Muñoz, Lab. Fisiologia Molecular i Canalopaties, Departament de Ciències Experimentals i de la Salut, Universitat Pompeu Fabra, C/ Dr. Aiguader 88, Barcelona 08003, Spain. Tel.: +34 9331608 52; Fax: +34 93316 09 01; E-mail: paco.munoz@upf.edu.
} 


\section{INTRODUCTION}

Amyloid- $\beta$ peptide $(A \beta)$ aggregates produce free radicals [1-3] that damage membrane proteins such as ATPases and ion channels, leading to an increase in intracellular calcium levels [4, 5]. Under these conditions, nitric oxide (NO) is produced by the activation of the neuronal NO synthase (nNOS), a $\mathrm{Ca}^{2+}$-calmodulin-dependent enzyme [6, 7]. NO can react with other molecules such as superoxide anion $\left(\mathrm{O}_{2}{ }^{-}\right)$to form peroxynitrite anion $\left(\mathrm{ONOO}^{-}\right)$[8], a short-lived but highly reactive molecule that nitrotyrosinates proteins. This modification is an irreversible reaction that adds a nitro group $\left(\mathrm{NO}_{2}\right)$ to a tyrosine residue, generating 3-nitrotyrosine [9, 10]. Consequently, nitrotyrosination is widespread in Alzheimer's disease (AD) brain [11, 12]. Antioxidants such as free radical scavengers [13] or inhibitors of NO production have been proposed to protect against $A \beta$ toxicity [14].

One of the proteins strongly nitrotyrosinated by $\mathrm{A} \beta$ action is triosephosphate isomerase (TPI) $[15,16]$. TPI catalyzes the interconversion of D-glyceraldehyde-3phosphate to dihydroxyacetone phosphate (DHAP). A key enzyme in cell metabolism, TPI controls glycolytic flow and ensures efficient energy production [17], which is essential to support normal cell activity.

Glucose is the primary source of energy for the brain. Any interruption of glycolysis causes brain dysfunction and memory loss, favoring neurodegeneration [18]. Isomerase deficiency is associated with neurodegeneration [19] and has been related to reduced longevity [20]. Moreover, TPI deficiency leads to the accumulation of its substrate DHAP, which can decompose non-enzymatically into methylglyoxal (MG), a cytotoxic precursor of advanced glycation endproducts (AGEs) [21]. MG acts as a potent glycative agent that triggers apoptosis in neurons [22, 23]. Protein glycation has been previously reported in $\mathrm{AD}$ brains $[16,24]$ and it would be contributing to the neuronal damage [25].

In AD patients, TPI is highly nitrotyrosinated [16, $26,27]$. We have previously reported that TPI nitrotyrosination by $A \beta$ action reduces the efficiency of its isomerase activity and leads TPI to adopt a $\beta$-sheet structure that favors tau aggregation into paired helical filaments, one of the AD hallmarks [16].

The present study analyzed the impact of nitroTPI on cell viability, proposing MG production as the mechanism behind the deleterious consequences of $\mathrm{A} \beta$-dependent TPI nitrotyrosination. We analyzed the toxic effects of treating neuroblastoma cells ( $\mathrm{SH}$ SY5Y) with $A \beta_{42}$ oligomers. In addition, we studied the effect of Tyr 165 and Tyr209 nitration, located close to the catalytic center of the enzyme, using the Phe mutation of Tyr that mimics the nitro-TPI structure. A computationally validated model of nitro-TPI was used to analyze its effects.

\section{MATERIALS AND METHODS}

\section{Tissue samples}

Human brain tissue sections were supplied by the Banc de Teixits Neurològics, Serveis CientíficoTècnics, Hospital Clínic, Universitat de Barcelona. Brain samples were obtained from the gyrus frontalis superior of the frontal cortex of five healthy individuals ( 3 males and 2 females aged 59.6 \pm 6.9 aged years) and five patients with $\mathrm{AD}$, at stage VI (2 males and 3 females; aged $72 \pm 4.5$ years). Human brain sample analysis was approved by the Ethics Committee for Clinical Investigation of the Institut Municipal d'Investigacions Médiques, Universitat Pompeu Fabra (IMIM-UPF Approval ID: 2010/3847/I). Written informed consent was obtained for all study participants.

\section{Immunohistochemistry of human brain samples}

Frontal cortex sections $(5 \mu \mathrm{m})$ were pre-treated with $50 \%$ formic acid for $1 \mathrm{~min}$ to expose TPI epitopes. Sections were incubated with rabbit anti-TPI polyclonal antibody (Ab) (1:500, Abcam, Cambridge, UK) or anti-argpyrimidine $\mathrm{Ab}(1: 500$, Cosmo Bio Co., Ltd, Tokyo, Japan) for $2 \mathrm{~h}$ at room temperature (RT), then incubated with donkey anti-rabbit peroxidaseconjugated $\mathrm{Ab}(1: 500)$ for $1 \mathrm{~h}$ at RT. Slides were treated with a DAB peroxidase substrate kit (Vector Lab). Samples were counterstained with hematoxylin, dehydrated, and mounted.

\section{Mice brain samples}

Cerebral paraffined slides from A $\beta$ PPswe/PS1 L166P mice were deparaffined with Clear Rite 3 and washed with decreasing ethanol dilutions. Briefly, slides were blocked for $1 \mathrm{~h}$ at room temperature with $2 \%$ normal serum in TNB buffer. The same solution was used to dilute $(1: 100)$ the anti-argpyrimidine (Cosmobio) antibody. The primary antibody was incubated overnight at $4^{\circ} \mathrm{C}$. The secondary antibody 
was further diluted $(1: 200)$. All washes were performed with TNT $1 \mathrm{X}$ buffer. Mice dissection followed E.U. guidelines for animal experimentation and was approved by the Ethics Committee for Animal Experimentation (IMIM-UPF; Approval ID: JMC-071001P1-PML).

\section{Overexpression of TPI in neuroblastoma cells}

TPI was amplified by PCR from purified human chromosomal DNA and cloned into a construct containing a 5' upstream flag sequence. Wild-type (WT) TPI and TPI carrying double tyrosine mutation (Y165F/Y209F) were produced and subcloned into a pcDNA3 plasmid. A human neuroblastoma cell line (SH-SY5Y) was seeded in 6-well plates at a density of $5 \times 10^{5}$ cells per well and grown for $24 \mathrm{~h}$ with Ham's F12 medium supplemented with $15 \%$ fetal bovine serum (FBS). Afterwards, $2 \mu \mathrm{g}$ per well of each construct were transfected using Lipofectamine 2000 Reagent (Invitrogen, Carlsbad, USA), following manufacturer instructions. After $3 \mathrm{~h}$, the medium was replaced by Ham's F12 medium plus 15\% FBS and 1\% penicillin/streptomycin.

\section{$A \beta_{42}$ oligomer preparation}

Synthetic $\mathrm{A} \beta_{42}$ (EZBiolab, Carmel, USA) oligomers were obtained by dissolving $300 \mu \mathrm{g}$ freezedried aliquots in $20 \mu \mathrm{L}$ DMSO. Peptide stock aliquots were diluted in $0.1 \mathrm{M}$ Tris- $\mathrm{HCl}$ at $\mathrm{pH} 7.4$ to a final concentration of $88.6 \mu \mathrm{M} \mathrm{A} \beta$. Solutions were stirred continuously at $37^{\circ} \mathrm{C}$ and $300 \mathrm{rpm}$ for $3 \mathrm{~h}$ and kept at $-80^{\circ} \mathrm{C}$ before being used (Supplementary Figure 1).

\section{$A \beta_{42}$ oligomer incubation with human neuroblastoma cells}

SH-SY5Y, a human neuroblastoma cell line (supplied by ECACC), was grown in Ham's F12 medium (Invitrogen) supplemented with $15 \%$ FBS and $1 \%$ streptomycin/penicillin at $37^{\circ} \mathrm{C}$ in a humidified atmosphere containing $5 \% \mathrm{CO}_{2}$. For cell viability and metabolism assays, cells were seeded into 96-well culture plates at a density of 25,000 cells $/ 200 \mu \mathrm{L}$ per well. For western blot analysis, cells were plated onto 60 $\mathrm{mm}$-diameter-dishes at a density of 700,000 cells $/ 3 \mathrm{~mL}$ per dish.

After $24 \mathrm{~h}$ in culture, cells were treated with different concentrations of $A \beta$ oligomers $(0.1,0.5$, and $1 \mu \mathrm{M})$ for $24 \mathrm{~h}$. Then the cells were lysed on ice with a solution containing $1 \mathrm{M}$ Tris- $\mathrm{HCl}, 1 \%$ Nonidet $\mathrm{P}-40$,
$150 \mathrm{mM} \mathrm{NaCl}, 5 \mathrm{mM}$ EDTA, $1 \mathrm{mM}$ sodium orthovanadate, $1 \mathrm{mM}$ dithiotreitol, $\mathrm{pH} 7.4$, and a protease inhibitor cocktail (Roche). Protein concentration was determined by Bradford assay.

Treatment of SH-SY5Y with hydrogen peroxide

$\left(\mathrm{H}_{2} \mathrm{O}_{2}\right)$, camptothecin, and scrambled $A \beta$

Cells were treated with different concentrations of scrambled WT $A \beta_{42}$ prepared as the WT $A \beta_{42}$ (0.1, 0.5 and $1 \mu \mathrm{M}$; rPeptide; Stratech Scientific), the pro-apoptotic inhibitor of DNA topoisomerase I camptothecin $(10,100,500$, and $1000 \mathrm{nM}$; Sigma) and $\mathrm{H}_{2} \mathrm{O}_{2},(1,10,100$, and $200 \mu \mathrm{M}$; Sigma) for $24 \mathrm{~h}$.

\section{Treatment of SH-SY5Y with aminoguanidine $(A G)$}

Cells were pre-treated with the MG scavenger AG (Sigma) at $250 \mu \mathrm{M}$ for $1 \mathrm{~h}$ before the addition of $A \beta$ oligomers for a $24 \mathrm{~h}$ treatment. In transfected cells, AG was added at the beginning of transfection.

\section{Incubation of SH-SY5Y overexpressing WT TPI} with conditioned medium

Cells overexpressing WT TPI were incubated during $24 \mathrm{~h}$ with the medium from cells overexpressing WT or YY TPI (conditioned medium).

\section{TPI immunoprecipitation}

$500 \mu \mathrm{g}$ of total protein from brains or SH-SY5Y cells lysates were incubated with $1.25 \mu \mathrm{g}$ of anti-TPI polyclonal Ab o.n. at $4^{\circ} \mathrm{C}$. Protein $\mathrm{G}$ immobilized on sepharose was added and samples were shaken for $2 \mathrm{~h}$ at RT. Aggregates were pulled down by centrifugation at $10,000 \mathrm{rpm}$ for $10 \mathrm{~min}$ and washed thrice. Protein $\mathrm{G}$ and $\mathrm{Ab}$ were seperated from the immunoprecipitated proteins by boiling the samples for $6 \mathrm{~min}$ at $100^{\circ} \mathrm{C}$.

\section{Western blot}

For analysis of cell homogenate aliquots, gels were transferred to PVDF membranes and incubated for $3 \mathrm{~h}$ at room temperature with one of 7 solutions: mouse anti-argpyrimidine monoclonal $\mathrm{Ab}(1: 1,000$; Cosmo Bio Co., Ltd), mouse anti-nitrotyrosine monoclonal Ab (1 : 1,000; Cayman Chemical, Michigan, USA), rabbit anti-cleaved caspase-3 (Asp175) Ab, rabbit anti$\operatorname{Bax} \mathrm{Ab}$ (1:1,000; Cell Signaling, Beverly, USA), mouse-anti TPI Ab (1:1,000; Abcam), rabbit anti Bcl-2 Ab (1:1,000; Cell Signaling), or mouse anti- 
A

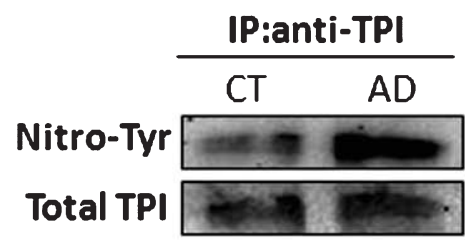

C
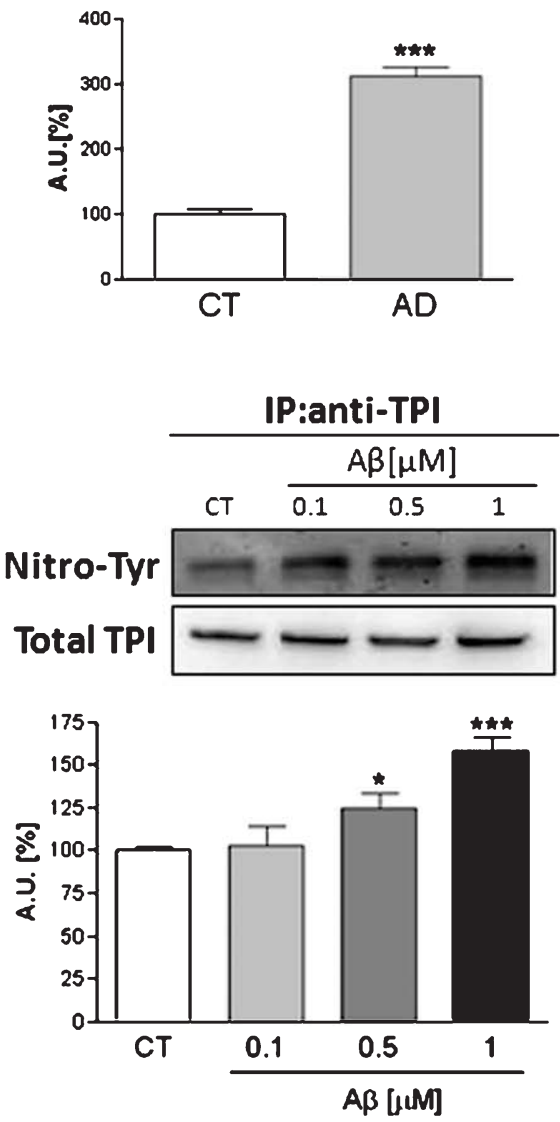

$\mathbf{E}$

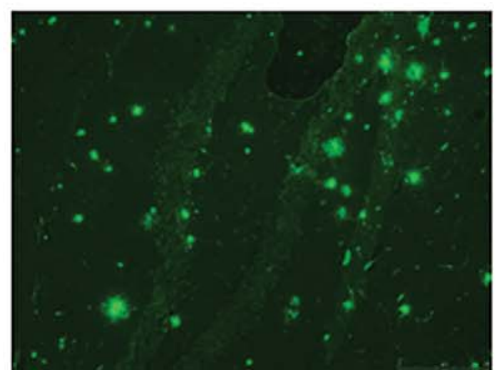

B

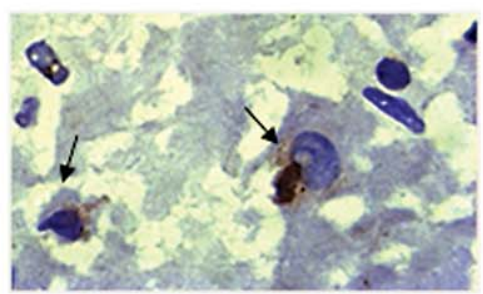

D
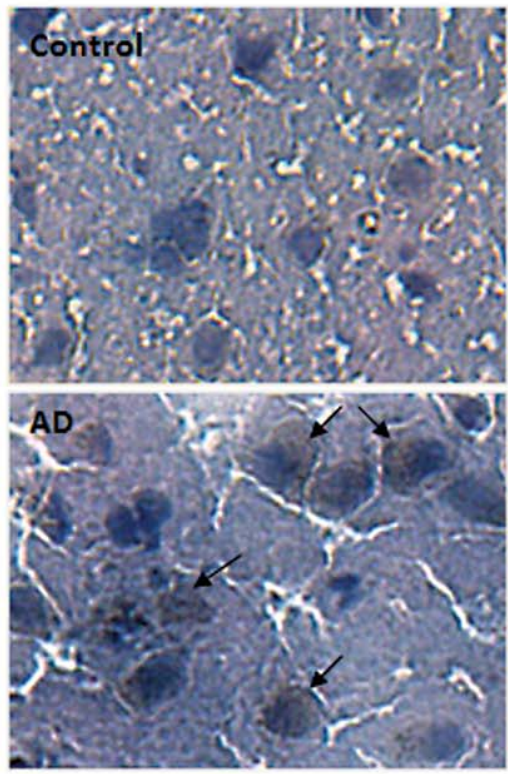

$\mathbf{F}$ $A \beta$

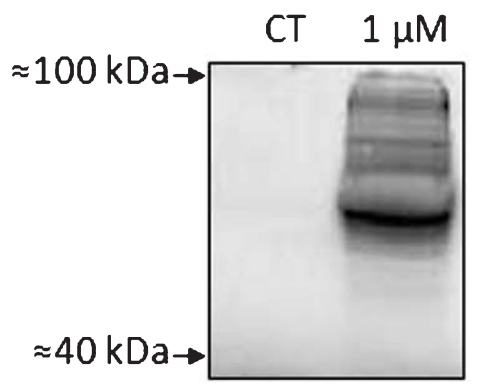

Fig. 1. TPI nitrotyrosination by A $\beta$ and MG production. A) Western blot of immunoprecipitated TPI from AD patient and non-demented (CT) frontal cortex. Quantifications are expressed as arbitrary units (AU). Data are mean \pm SEM of 4 independent experiments. ${ }^{* * *} p<0.001$ versus control by Student's $t$-test. B) A representative image of intracellular TPI aggregates in AD frontal cortex analyzed by immunohistochemistry. C) Western blot of immunoprecipitated TPI from SH-SY5Y cells treated with increasing concentrations of $\mathrm{A} \beta_{42}$ oligomers for $24 \mathrm{~h}$. Blots were performed with anti-nitrotyrosine and anti-TPI Abs. Data are mean \pm SEM of 3 independent experiments. ${ }^{*} p<0.05,{ }^{* *} p<0.01$ versus control by Student's $t$-test. D) AD patient and non-demented frontal cortex sections immunostained with an anti-argpyrimidine Ab. Positive staining is shown in AD patient (arrows). E) Hippocampus from double transgenic mice overexpressing A $\beta P P$ and PS1 immunostained with an anti-argpyrimidine $\mathrm{Ab}$. F) Representative western blot of SH-SY5Y cells challenged with $1 \mu \mathrm{M}$ A $\beta_{42}$ oligomers for $24 \mathrm{~h}$. Glycation was analyzed using anti-argpyrimidine $\mathrm{Ab}$. 
$\beta$-actin monoclonal Ab (1:5,000, Sigma, St. Louis, USA). Membranes were incubated with peroxidaseconjugated secondary Ab (1:3,000; GE-Healthcare, $\mathrm{UK}$ ) for $1 \mathrm{~h}$ at RT. Bands were visualized using the enhanced chemiluminescence substrate (Super Signal; Pierce).

\section{Immunocytochemistry of SH-SY5Y}

After $24 \mathrm{~h}$, cells were fixed with $4 \%$ paraformaldehyde and permeabilized with $0.1 \%$ Triton X-100. SH-SY5Y cells were immunostained with $1: 100$ mouse monoclonal anti-methylglyoxal Ab (Cosmo Bio Co., Ltd.) and 1 : 2,000 Alexa 555-bound as secondary $\mathrm{Ab}$ (Sigma) at RT. Transfected cells were positive for EGFP fluorescence. Coverslips were mounted and analyzed using a Leica TCS SP confocal microscope and analyzed with Leica confocal software.

\section{Cell viability assays}

SH-SY5Y cells were seeded in 96-well plates at a density of 25,000 cells $/ 200 \mu \mathrm{L}$, incubated $24 \mathrm{~h}$, and tested for viability by 3-(4,5-dimethylthiazol-2-yl)2,5-diphenyltetrazolium bromide (MTT) reduction. Briefly, $11 \mu \mathrm{L}$ of MTT stock solution $(5 \mathrm{mg} / \mathrm{mL})$ were added; after $2 \mathrm{~h}$ the reaction was stopped with $120 \mu \mathrm{L}$ of DMSO. MTT reduction was determined in a plate reader spectrophotometer at 540 and $650 \mathrm{~nm}$. Control cells were taken as $100 \%$.

\section{Measurement of $\Delta \Psi_{m}$}

SH-SY5Y cells were re-suspended at $10^{6}$ cells $/ \mathrm{mL}$ in PBS with the fluorophore MitoTracker Red CMXRos (Molecular Probes, Carlsbad, USA). Cells were incubated for $10 \mathrm{~min}$ at $37^{\circ} \mathrm{C}$ and analyzed in a FACScan (Becton Dickinson, CA).

\section{Liquid chromatography-Mass spectrometry (LC-MS/MS) experiments}

Commercial TPI from rabbit (Sigma) was reduced and alkylated prior to trypsinization in solution. Tryptic peptides were desalted using C18 type stage tip41 [28] prior to analysis by reversed phase nano LC-MS/MS on an Orbitrap Velos (ThermoScientific, Bremen, Germany) mass spectrometer in higher-energy collisional dissociation (HCD) mode. MS/MS spectra were extracted using ProteomeDiscoverer 1.3 (ThermoScientific, Bremen Germany) and searched against SwissProt mammalian using MASCOT. Mass toler- ance of $10 \mathrm{ppm}$ and $20 \mathrm{mDa}$ was used for precursor and fragment ions, respectively.

\section{Computational modelling of the effect of Phe and nitroTyr substitutions on Y165 and Y209}

Two structures were taken from the PDB as representatives of the open and closed states of TPI, namely $1 \mathrm{I} 45$ and $1 \mathrm{NEY}$, respectively. The structures were processed with the Schrodinger's Maestro 9.2.109 suite for missing heavy atoms and hydrogens, as well as to transform fluoro-tryptophan residues into tryptophan. The optimal hydrogen bond network (providing optimal protonation states to His residues and optimizing the orientation of the protein side chains) was obtained with the protein preparation wizard in the same suite. Mutations were then introduced in order to build the Y165F and Y165n systems from the openstate wt structure (1I45) and the Y209F and Y209n systems from the closed-state wt structure (1NEY). The six structures were independently solvated with the Impact/soak module in maestro, in a cube of TIP3P water molecules with $60 \times 60 \times 60 \AA^{3}$ around the mass center of each protein. We ran $1 \mathrm{~ns}$ molecular dynamics (MD) simulations with periodic boundary conditions and a $12 \AA$ cut-off radius for non-bonded interactions (updating non-bonded lists every 10 steps) on the different systems, while keeping fixed the protein atoms in order to relax the water molecule positions. After MD runs, the final snapshots were taken as input for the Quantum Mechanics/Molecular Mechanics $(\mathrm{QM} / \mathrm{MM})$ runs.

All QM/MM calculations were performed with the Qsite program, taking as QM region the residues directly involved in the hydrogen-bonding networks of interest. This involved residues $164-166$ and the side chain of 169 in the open state and 176-178, 208-210 in the closed state. With these settings, QM regions included 48 to 74 atoms, depending on the system. QM/MM minimizations where performed with a truncated Newton optimizer for the MM. A sphere of radius $10 \AA$ was built around the centroid of the QM region to define the region to be minimized, leaving fixed throughout the simulation the water molecules beyond that radius. Density functional theory computations using the non-local hybrid Becke three-parameter exchange function (denoted as B3LYP) with the 6$31 \mathrm{G}^{*}$ basis set as implemented in Jaguar were chosen to describe the energy of the QM region and the frozen orbital method was used to describe the QM-MM interface. Molecular graphics images were produced using the UCSF Chimera package from the Resource for 
Biocomputing, Visualization, and Informatics at the University of California, San Francisco (supported by NIH P41 RR001081).

\section{Genetic study of TPI polymorphisms}

The biallelic polymorphism rs2001004, located in the first intron of the TPI, was selected to be typed because it has been validated and has an estimated minor allele frequency in European populations around 0.34 (http://www.hapmap.org). Genotyping was conducted by TaqMan Assays-on-Demand on the ABI PRISMs 7900HT Sequence Detection System (Applied Biosystems, Carlsbad, California), followed by analysis with SDS 7500 software, version 2.0.1 (Applied Byosystems, Carlsbad, California).

The SNP was typed in 231 individuals diagnosed with $\mathrm{AD}$ (mean age at onset of $76.4 \pm 5.6$ years, $73.5 \%$ women) and 136 cognitively healthy control individuals (mean age at blood extraction, $71.7 \pm 9.4$ years; $58 \%$ women). For all patients, the diagnosis was established according to the National Institute on Neurological Disorders and Stroke, and the Alzheimer Disease and Related Disorders Association (NINDSADRDA) guidelines [29]. All samples were recruited from Fundació ACE and written informed consent was obtained from all participants or surrogates.

\section{Statistical analysis}

Data were expressed as the mean \pm SEM of the values from the number of experiments as indicated in the corresponding figures. Continuous data were evaluated by Student's $t$-test. Genotype and allele frequencies were estimated by direct counting and were compared between patients and controls by Chi-square analysis with one degree of freedom.

\section{RESULTS}

\section{TPI nitrotyrosination and the consequent $M G$} production in $A D$ are due to $A \beta$ action

As previously reported [16], we found that TPI is highly nitrotyrosinated in the brain of $\mathrm{AD}$ patients, as obtained by western blot and nitrotyrosination quantification regarding the protein levels (Fig. 1A), where it forms big intracellular aggregates (Fig. 1B). Therefore, we prepared $A \beta$ oligomers, characterized by western blot analysis (Supplementary Figure 1), and we found that the challenge of human neuroblastoma cells with increasing concentrations of $\mathrm{A} \beta$ oligomers pro- duced a proportional increase in TPI nitrotyrosination (Fig. 1C), reinforcing that TPI nitrotyrosination is due to $A \beta$ action $[15,30]$.

MG is synthesized at a very low rate as a byproduct from TPI isomerase activity, but its production is strongly increased by TPI nitrotyrosination [16]. Specifically, MG binds to and modifies arginine, cysteine, and lysine residues in proteins, which causes a non-enzymatic formation of different AGEs such as argpyrimidine, $N \varepsilon$-(carboxyethyl) lysine, hydroimidazolones $N \varepsilon$-(5-hydro-5-methyl-4-imidazolon-2-yl)ornithine, and methyl-glyoxal-lysine dimer [31]. We studied the glycative modification of arginine to argpyrimidine as one of the most representative parameters of protein glycation due to MG. Here we analyzed the protein glycation in the cortex from an $\mathrm{AD}$ patient, confirming higher MG production than that of an agematched, non-demented control (Fig. 1D); this concurs with previous results demonstrating protein glycation in AD brain [16]. Strong labeling for glycation was also observed in the hippocampus of an AD mouse model overexpressing A $\beta$ PP and PS1 (Fig. 1E). Furthermore, high levels of protein glycation was obtained when human neuroblastoma cells were challenged with $A \beta$ oligomers (Fig. 1F).

\section{A $\beta$ treatment induces apoptosis in human neuroblastoma cells}

$\mathrm{A} \beta$ aggregates are supposed to induce the characteristic neurodegeneration that produces $\mathrm{AD}$ [32]. Thus we addressed a study of the effects of $A \beta$ oligomers on apoptosis in human neuroblastoma cells. First we studied cell viability after $24 \mathrm{~h}$ challenges with increasing concentrations of $\mathrm{A} \beta$ oligomers (Fig. 2A). $\mathrm{A} \beta$ oligomers were significantly toxic for neuroblastoma cells from 0.1 to $1 \mu \mathrm{M}$ and the toxicity was dose-dependent (Fig. 2A). These experiments were carried out in parallel with the study on glucose uptake (Supplementary Figure 2), a parameter of the cell metabolism state. Glucose uptake was slightly but significantly reduced with all the $A \beta$ oligomers concentrations assayed in a pattern similar to that of cell viability.

Next we analyzed the reduction in cell viability induced by $A \beta$ oligomers. One of the early intracellular events that occurs in apoptosis is the abnormal opening of the mitochondrial transition pore by the collapse of mitochondrial transmembrane potential $(\Delta \Psi \mathrm{m})$, which results in a rapid release of caspase activators [33]. The pro-apoptotic effector Bax is a major mediator in this early apoptotic event. Bax levels were 
A
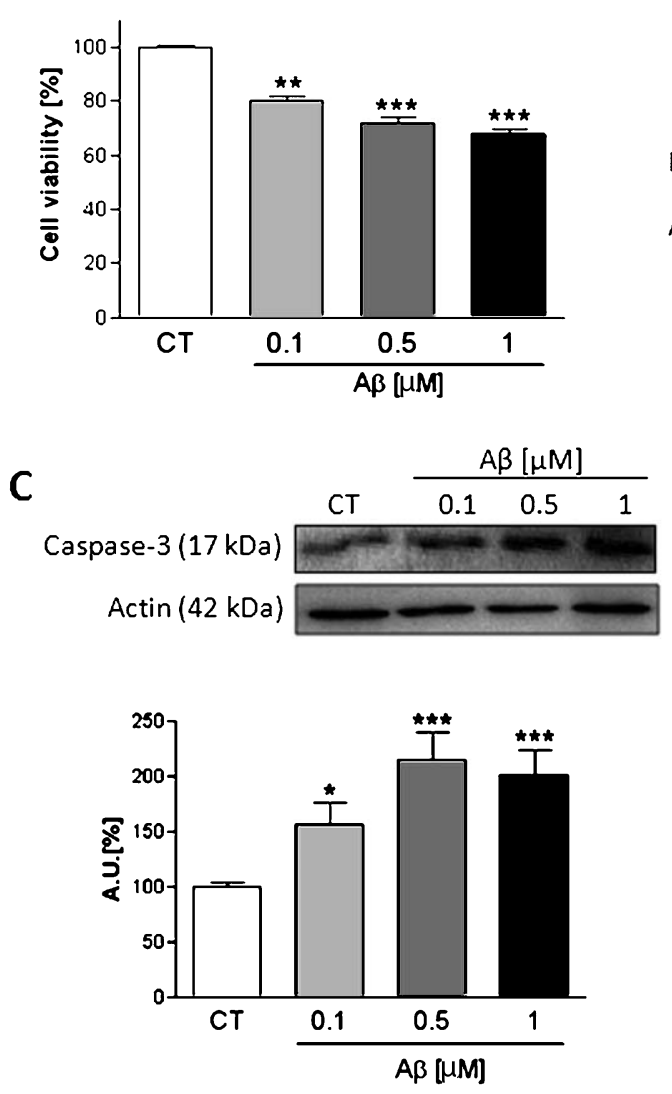

B
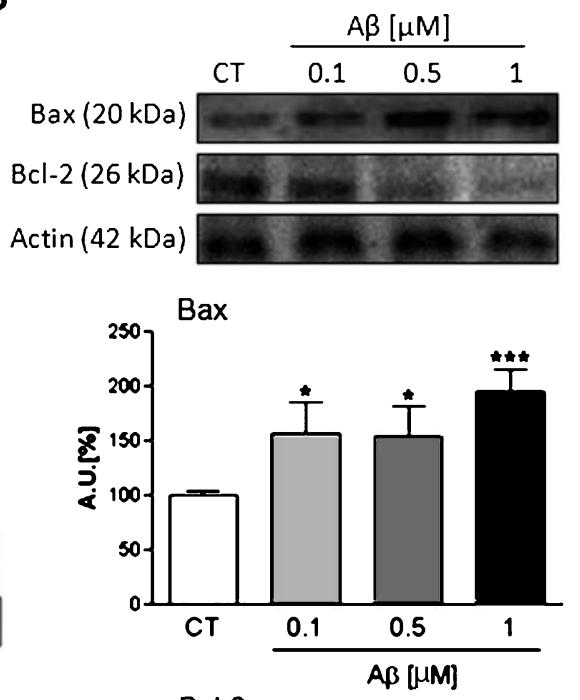

$\mathrm{Bcl}-2$

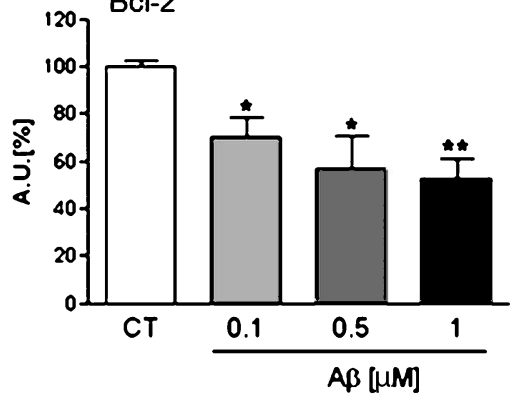

Fig. 2. Decreased cell viability and enhancement of apoptosis in neuroblastoma cells challenged with A $\beta$ oligomers. A) Cells challenged with increasing concentrations of A $\beta$ oligomers assayed by MTT reduction. Data are mean \pm SEM of 6 independent experiments performed by triplicate. ${ }^{* *} p<0.01,{ }^{* * *} p<0.001$ versus control by Student's $t$-test. B) Western blot analysis of pro-apoptotic Bax and anti-apoptotic Bcl-2 levels in cells challenged with increasing concentrations of $\mathrm{A} \beta$ oligomers. Quantifications expressed as AU are shown in the graphs. Data are mean $\pm \mathrm{SEM}$ of 6 independent experiments. ${ }^{*} p<0.05,{ }^{* *} p<0.01,{ }^{* * *} p<0.001$ versus control by Student's $t$-test. C) Western blot analysis of activated caspase-3 levels in cells treated with $\mathrm{A} \beta(\mathrm{A})$ at different concentrations. It was quantified and expressed as AU. Data are mean \pm SEM of 6 independent experiments. ${ }^{*} p<0.05,{ }^{* *} p<0.01,{ }^{* * *} p<0.001$ by Student's $t$-test.

significantly increased when human neuroblastoma cells were challenged with $A \beta$ oligomers (Fig. 2B). On the other hand, analysis of the protective anti-apoptotic protein Bcl-2 levels (Fig. 2B) showed that neuroblastoma cells had significantly decreased levels of Bcl-2 when challenged by $\mathrm{A} \beta$ oligomers, making them more prone to apoptosis.

Caspase- 3 is downstream of the activation of intracellular apoptotic pathways and has been shown to be elevated in AD model mice [34] and AD patient brains [35]. As expected after the proapoptotic changes we observed in mitochondria, $A \beta$ oligomers significantly increased the levels of active caspase- 3 compared to non-treated human neuroblastoma cells (Fig. 2C).

To confirm that TPI nitrotyrosination results from the $A \beta$-induced oxidative stress, we challenged neuroblastoma cells with scrambled $A \beta_{42}$, a scrambled peptide with the same amino acids as in human $\mathrm{A} \beta_{42}$, and cell viability was unchanged (Supplementary Figure 3A). As expected TPI nitrotyrosination was not increased by scrambled $A \beta_{42}$ treatment (Supplementary Figure 3B). Furthermore we challenged neuroblastoma cells with $\mathrm{H}_{2} \mathrm{O}_{2}$, an inducer of oxidative stress, and camptothecin, a proapoptotic inhibitor of DNA topoisomerase I. Both compounds triggered apoptosis (Supplementary Figure 4A, C) but only $\mathrm{H}_{2} \mathrm{O}_{2}$, which generates reactive oxygen species, induced TPI nitrotyrosination (Supplementary Figure 4D). To support the relevance of MG in A $\beta$ toxicity, we preincubated neuroblastoma cells with AG (Fig. 3 and Supplementary Figure 5), a well-known MG scavenger [36, 37]. After $24 \mathrm{~h}$ challenge with $A \beta$ oligomers, we obtained a significant protection in cell viability when cells were preincubated with $\mathrm{AG}(p<0.01$; 
A

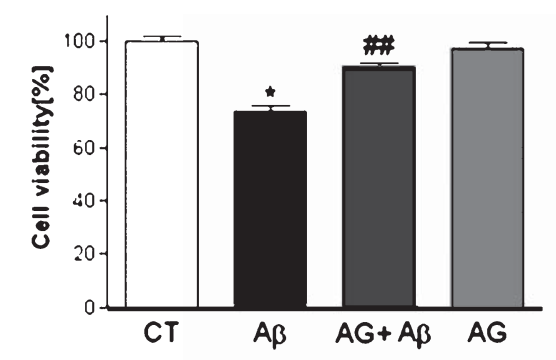

C
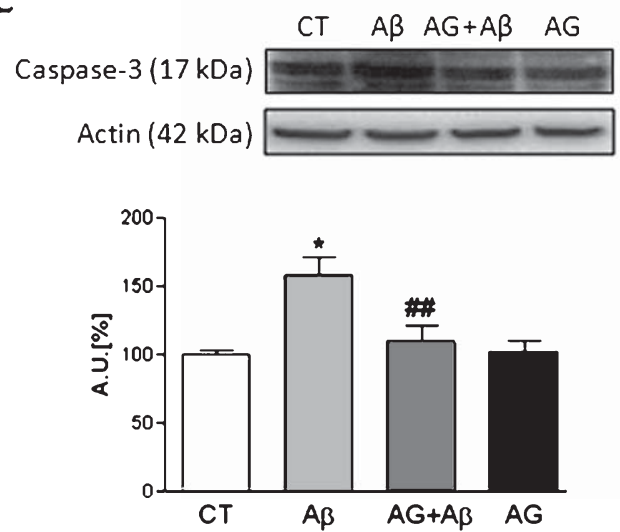

B
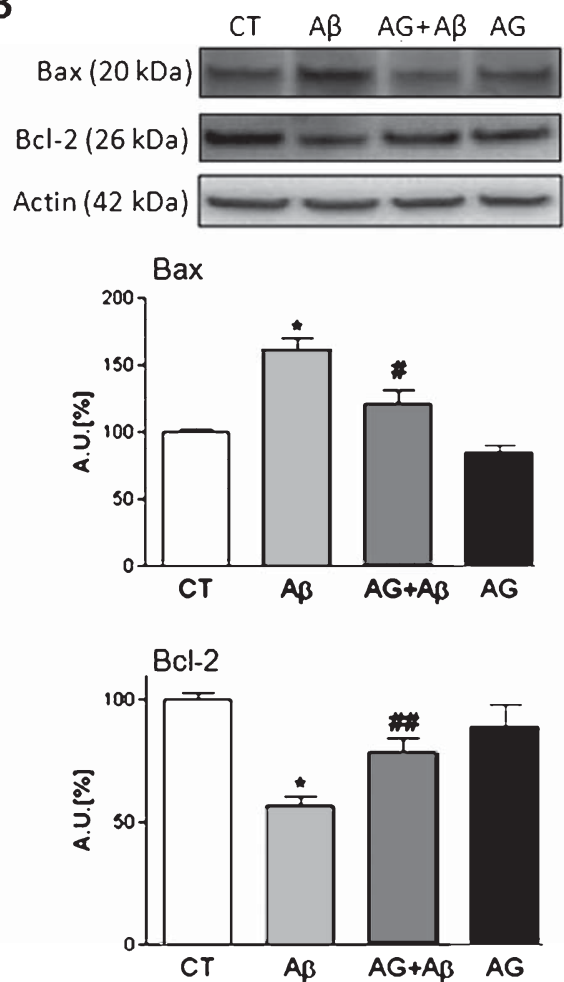

Fig. 3. Decreased A $\beta$ toxicity on neuroblastoma cells pretreated with AG, a MG scavenger. A) Cell viability assay by MTT reduction after $24 \mathrm{~h}$ of $\mathrm{A} \beta$ treatment. Data are mean \pm SEM of 6 independent experiments performed by triplicate. ${ }^{*} p<0.001$ versus control; \#\# $p<0.01$ versus $A \beta$ treated cells by Student's $t$-test. B) Western blot analysis of Bax and Bcl-2 levels in cells challenged with $A \beta$ oligomers and A $\beta$ plus AG for $24 \mathrm{~h}$. Quantifications expressed as AU are shown in the graphs. Data are mean \pm SEM of 6 independent experiments. ${ }^{*} p<0.001$ versus control;

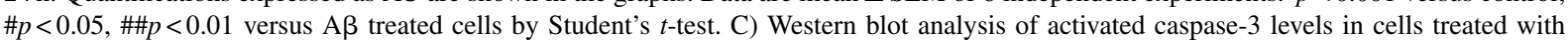
$\mathrm{A} \beta$ and $\mathrm{A} \beta$ plus AG. It was quantified and expressed as AU. Data are mean \pm SEM of 6 independent experiments. ${ }^{*} p<0.001$ versus control; $\# \# p 0.01$ versus $\mathrm{A} \beta$ treated cells by Student's $t$-test.

Fig. 3A). Moreover, we analyzed the levels of proand anti-apoptotic proteins in the same conditions. Assayed by western blot, preincubation with AG produced a significant increase in the protective $\mathrm{Bcl}-2$ levels $(p<0.01$; Fig. 3B) and a decrease in the proapoptotics Bax and Caspase-3 $(p<0.05$ and $p<0.01$, respectively; Figs. 3B, C).

\section{$M G$ production is due to the nitration of the two tyrosines close to the catalytic center of the TPI}

A $\beta$ oligomers provoke the nitrotyrosination of TPI and this modified TPI produces an increase in the harmful byproduct MG [16]. We studied how nitrotyrosination affects TPI to produce a burst of MG production. The TPI monomer has four tyrosines: Tyr47 and Tyr67 stay at the interface of the dimer in opposite orientations, so tyrosines from different monomers do not face each other, while the remaining Tyr165 and Tyr209 are interacting in a direct way and sit very close to the catalytic site, making them critical elements of catalytic dysfunction (Supplementary Figure 6).

To analyze the nitration ability of the two tyrosine residues in close proximity to the catalytic center, we used a proteomic-based mass spectrometry strategy. TPI protein was treated with SIN-1 (a peroxynitrite donor), then trypsinized and analyzed by LC-MS/MS (Supplementary Figure 7). Peptides assigned as being nitrated on tyrosine residues were validated manually: IIY(NO2)GGSVTGATCK (Supplementary Figure 7A) and VVLAY(NO2)EPVWAIGTGK (Supplementary Figure 7B). The LC-MS/MS experiment was not designed as a quantitative study. However, assuming no major difference in ionization and digestion efficiency of the tyrosine-nitrated peptide compared to unmodified peptides, we used the area under the curve for each peptide to estimate the percentage of a residue that is modified. In our calculations, $5 \%$ to $8 \%$ of a given tyrosine residue was 


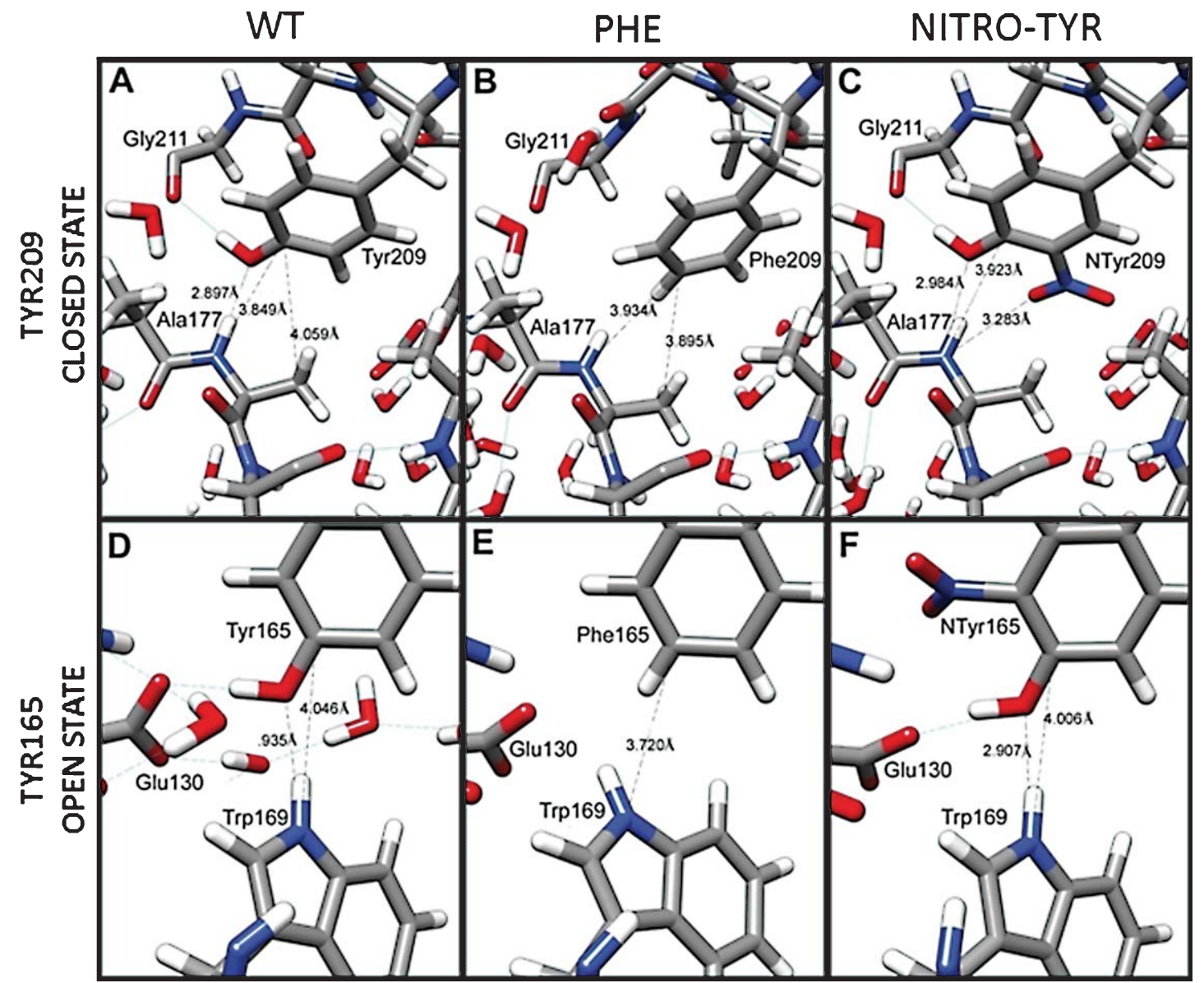

Fig. 4. Computational modelling of the effect of Phe and nitroTyr substitutions on Tyr165 and Tyr209. Equilibrium structures obtained by hybrid QM/MM optimizations of the regions surrounding the two key hydrogen bonds in which Tyr 165 and Tyr209 are, respectively, involved. The first row corresponds to the region containing the characteristic Y209-A177 HB in the closed state (based on the structure with PDB code 1 NEY) in three different systems, namely (A) wt TPI, (B) Y209F, and (C) Y209n, with $n=$ nitrotyrosine. The second row corresponds to the region containing the characteristic Y165-W169 HB in the open state (based on the structure with PDB code 1I45) in three different systems, namely (D) wt TPI, (E) Y165F, and (F) Y165n. Images were produced with Chimera.

nitrated in vitro. This percentage is similar to the $\sim 10 \%$ reported for nitrotyrosination in general in vitro assays [38].

On the other hand, computer models provide valuable understanding of protein activity, structure, and folding. They can also be used to study conformational changes induced by mutations or modifications of the protein and to predict if such alterations could have an effect on protein enzymatic activity. Having demonstrated that both tyrosines can be nitrated experimentally, we conducted a computational analysis of the conformational impact of nitrotyrosination on the catalytic domain of the enzyme. In addition, we confirmed that a double mutant TPI that we have generated (Y165F/Y209F) mimics this new conformation and we validated it as a tool for understanding the impact of nitrotyrosination on cell viability. The tyrosines were substituted by phenylalanines because they have a similar size and structure, and Phe is not able to establish the biochemical interactions with the surrounding amino acids, as nitro-Tyr does.

The TPI 3D structure defines the so-called "TIM barrel" fold, a regular eight-fold repeating pattern of $\beta$-strands and $\alpha$-helices. Loop 6 is very flexible and plays an important role in substrate binding and catalysis [39]. We hypothesized that TPI nitrotyrosination at Tyr165 and Tyr209 will destabilize the closed state of loop 6 [16], mainly due to the weakening of the H-bond interaction Tyr209-Ala177 (Supplementary Figure 6), and that this affects the efficiency of the enzyme. Furthermore, the electron withdrawal effect of the nitro substituent in the phenol ring of tyro- 
A
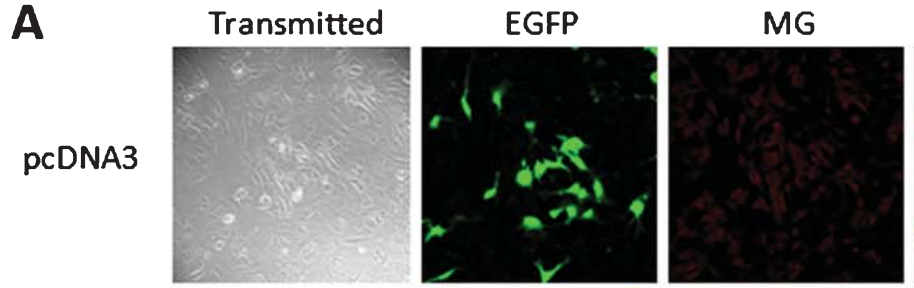

merge
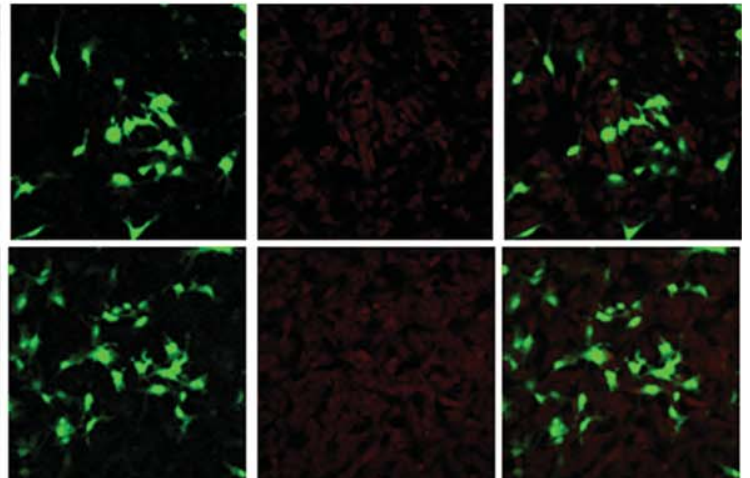

WT
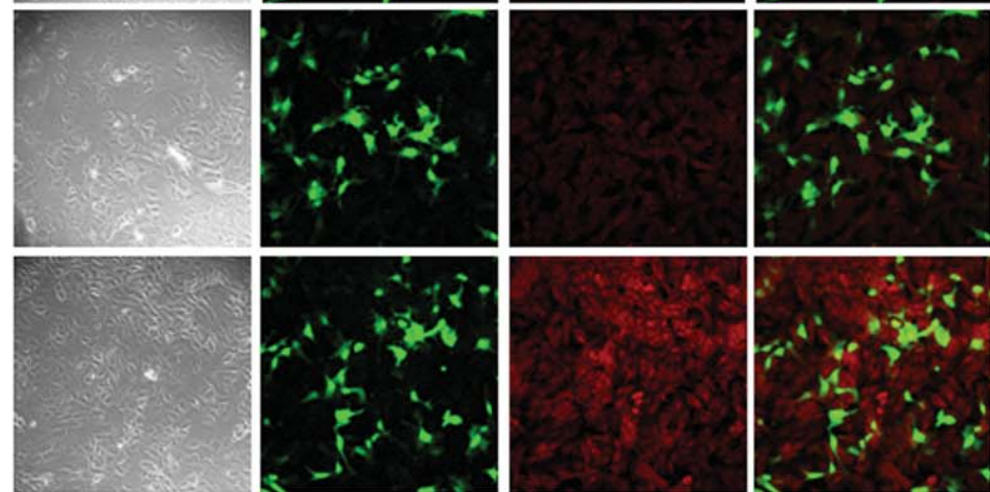

YY
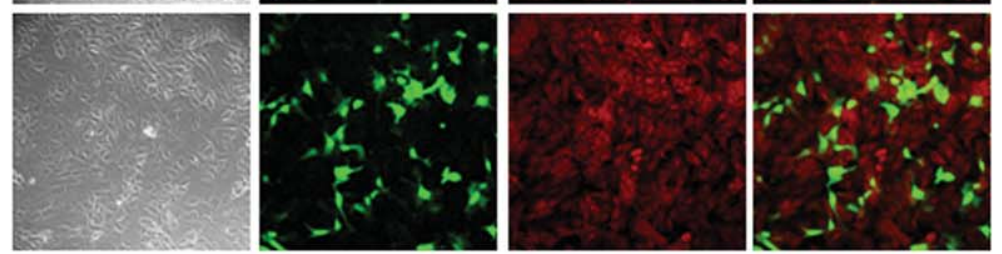

WT+

WT media
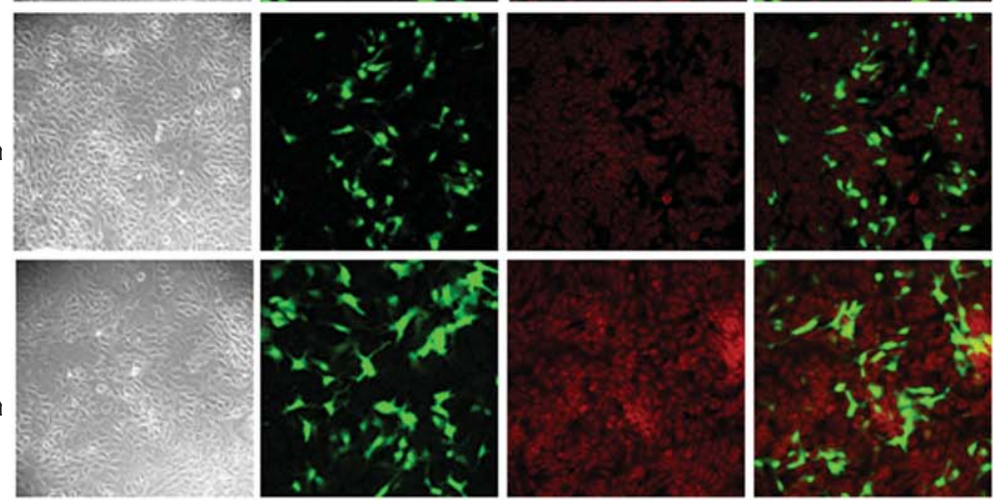

B

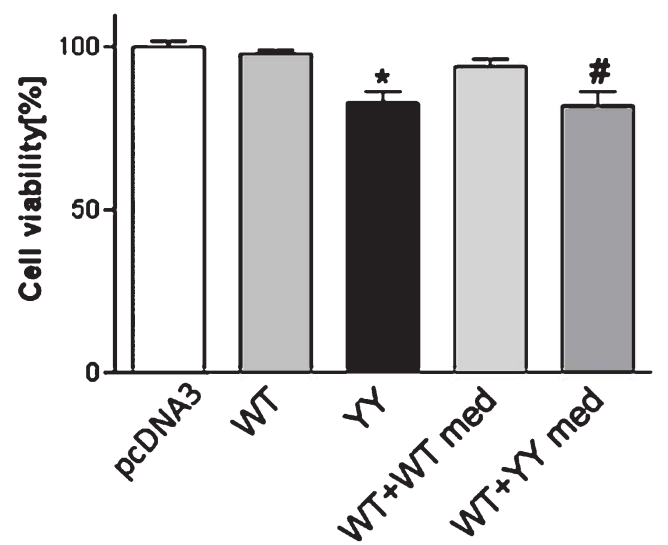

Fig. 5. MG production in neuroblastoma cells overexpressing WT or YY TPI. A) Cells were untreated, treated with AG, or incubated with conditioned media from cells overexpressing WT TPI or YY TPI. Glycation was studied with an anti-argpyrimidine Ab (red staining). pcDNA3 was used as the transfection control. Transfected cells were EGFP positive (green staining). Images were analyzed by confocal microscopy. B) Cell viability of normal transfected cells or incubated with the conditioned medium from cells overexpressing YY TPI. It was assayed by MTT reduction. Data are mean \pm SEM of 3 independent experiments performed by triplicate. ${ }^{*} p<0.01$ versus control; \#p<0.01 versus WT TPI by Student's $t$-test. 
A

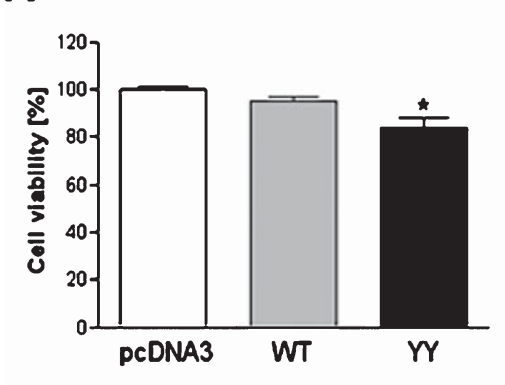

C
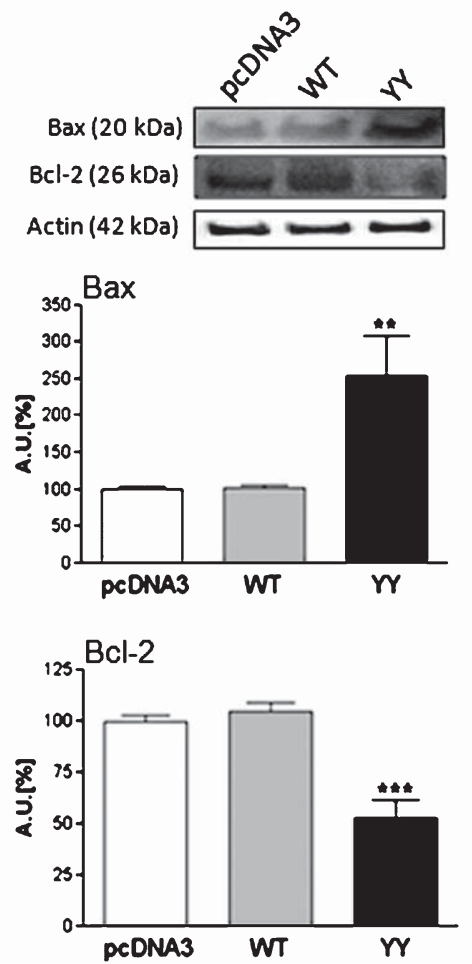

B
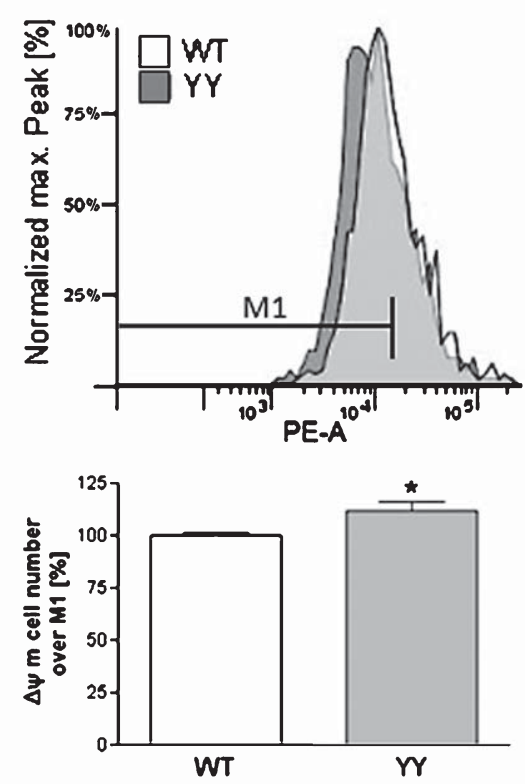

D
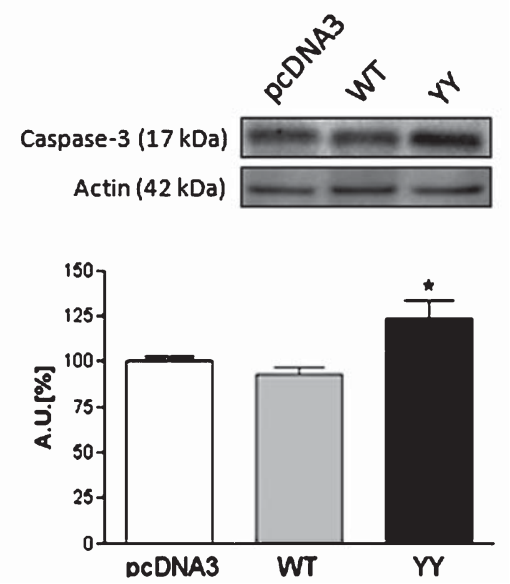

Fig. 6. Increased apoptosis in neuroblastoma cells overexpressing double-mutant TPI Y165F/Y209F. A) Cell viability measurement of the transfected cells. Data are mean \pm SEM of 3 independent experiments performed by triplicate. ${ }^{*} p<0.01$ versus cells overexpressing WT TPI by Student's $t$-test. B) Representative graph of $\Delta \Psi \mathrm{m}$ in cells overexpressing WT TPI or YY TPI assayed by flow cytometry and MitoTracker staining. The quantification of cells with low $\Delta \Psi \mathrm{m}$ is expressed as percentage of WT TPI. Data are mean \pm SEM of 4 independent experiments performed by triplicate. ${ }^{*} p<0.05$ versus cells overexpressing WT TPI by Student's $t$-test. C, D) Western blot analysis of Bax, Bcl-2 (C) and caspase-3 (D) levels in cells overexpressing WT TPI or YY TPI. Quantifications expressed as arbitrary units (AU) are shown in the graphs. Data are mean \pm SEM of 4 independent experiments. ${ }^{*} p<0.05 ;{ }^{* *} p<0.01 ;{ }^{* * *} p<0.001$ versus cells overexpressing WT TPI by Student's $t$-test.

sine must be a related factor. To test this hypothesis and to understand how the mutation of tyrosine by phenylalanine may be mimicking the effect of nitrotyrosination, we performed a battery of hybrid QM/MM structural calculations on the H-bond network around Tyr165 and Tyr209. Figure 4 summarizes the results of the QM/MM calculations, which were conducted after short MD simulations to relax the positions of the water molecules in the vicinity of the key hydro- gen bonds (see Materials and Methods). The figure is divided in two rows, corresponding to the closed state of TPI (upper row, Fig. 4A-C) and to its open state (lower row, Fig. 4D-F). The different subfigures show the relevant distances defining the hydrogen bond network after a standard MD protocol to relax the solvent molecules while keeping the substrate (the protein atoms) fixed, followed by minimization of a complete QM/MM system centered in the relevant $\mathrm{H}$-bond. 
The results for the closed state (based on simulations and minimization, PDB code $1 \mathrm{NEY}$, see Materials and Methods) show a reasonably similar environment around the Tyr209-Ala177 H-bond interaction in the different models (Fig. 4A-C). In fact, practically the same water molecules are found close to the H-bond. This helps to compare X209-Ala177 distances for the three systems with $X=$ Tyr, Phe, NTyr. The distance between the hydroxyl oxygen in Tyr209 and the main chain $\mathrm{N}$ atom in Ala177 slightly increases when modified by nitrotyrosination of Tyr209, and the linearity of the H-Bond is also decreased (Fig. 4C). There are two reasons for this. On one hand, the electron withdrawal effect of the nitro group decreases the charge in the hydroxyl oxygen. On the other, the presence of competitor nitro oxygen essentially delocalizes this $\mathrm{H}$ bond. Furthermore, the nitro group can exert a steric effect, which can perturb and destabilize the H-bond network. The increase in the X209-A177 distance is slightly larger for the Y209F substitution, as expected (Fig. 4B).

As for the open state, here the polarity of the environment around the Tyr165-Trp169 H-bond changes drastically in the mutated system Y165F and in the modified Y165n (with $n$ representing nitrotyrosine) (Fig. 4D-F). For the wild-type system, the strongly polar environment produces a relatively mild H-bond interaction that keeps loop 6 in the open state (Fig. 4D). When we move to the Y165F mutant or to the nitrated tyrosine, the situation changes and the environment becomes relatively non-polar (Fig. 4E-F). This, in turn, enhances the interaction in the Y165n-W169 system, creating a stronger $\mathrm{H}$-bond that may help to keep loop 6 in its open conformation for longer periods of time. In the case of the Y165F mutation, removing the Tyr165 hydroxyl group and reducing the polarity of the immediate environment helps the Phe165 residue to approach W169, compacting the system much the same as Y165n does.

Overall, Y209 and Y165 nitration helps to avoid the closure of loop 6 and to keep it open, respectively, producing the effect of increasing $\mathrm{K}_{\mathrm{M}}$ (lower affinity of the ligand by its substrate) and decreasing $\mathrm{k}_{\mathrm{cat}} / \mathrm{K}_{\mathrm{M}}$ (lower enzymatic activity) [16].

\section{Increase in MG production in neuroblastoma cells transfected with the double mutant TPI}

TPI nitrotyrosination results in reduced catalytic activity and increased occupancy of the enzyme by the substrate, and consequently, a higher production of toxic MG [16]. TPI prevents MG production by holding its loop 6 over the catalytic center when the substrate binds. Nitration of Tyr165 keeps loop 6 open via a hydrogen bond with Thr168, allowing the entry of water into the active site, which results in the hydrolysis of the intermediate enediol phosphate that yields MG.

This hypothesis was supported by the computational analysis and confirmed using human neuroblastoma cells overexpressing WT and mutant TPI at Tyr165Phe and Tyr209Phe (YY TPI), the two nitrated residues close to the catalytic center (Fig. 5). These mutations mimic the effect of nitrotyrosination on loop stability.

Cells overexpressing YY TPI showed an increase in $\mathrm{MG}$ production, detected by immunofluorescence (Fig. 5A) and western blot (Supplementary Figure 8). MG diffuses easily. We found that cells overexpressing WT TPI incubated with conditioned medium from cells overexpressing YY TPI showed wide protein glycation (Fig. 5A), but the same cells incubated with conditioned medium from cells overexpressing WT TPI did not show any glycative stress (Fig. 5A). The effects of MG in cell death were also studied. We observed a reduction in cell viability when cells overexpressing WT TPI were incubated with medium from cells overexpressing YY TPI $(p<0.01$; Fig. 5B).

\section{Increased apoptotic events in human neuroblastoma cells overexpressing the double mutant TPI Y165F/Y209F}

Considering that the double mutant Y165F/Y209F mimicked the MG production induced by $A \beta$ mediated TPI nitrotyrosination we analyzed the impact of mutant TPI expression on cell survival (Fig. 6). We observed a pattern consistent with a pro-apoptotic state: significant reduction in cell viability in cells transfected with the double mutant TPI compared to the WT TPI transfected cells (Fig. 6A). Moreover, we studied the apoptotic events, starting with the $\Delta \Psi_{\mathrm{m}}$ (Fig. 6B). We found that cells overexpressing double-mutant TPI had lower $\Delta \Psi_{\mathrm{m}}$ compared to cells overexpressing WT TPI, suggesting a mitochondrial dysfunction. We also observed a significant increase in Bax levels and decrease in Bcl-2 in cells overexpressing double-mutant TPI (Fig. 6C). These early apoptosis events were in accordance with the increase in active caspase-3 levels we observed in cells transfected with double-mutant TPI compared to WT-TPI transfected cells (Fig. 6D). A direct glycative effect on the studied apoptotic proteins (Bax, Bcl-2 and caspase-3) was discarded by western blot analysis (Supplementary Figure 9). 
Table 1

Genotype and allelic distribution of TPI SNP (rs2001004) analyzed in $\mathrm{AD}$ cases and control subjects

\begin{tabular}{lcc}
\hline & AD Cases & Controls \\
\hline Genotypes & & \\
AA & $105(0.454)$ & $54(0.397)$ \\
AG & $92(0.398)$ & $64(0.471)$ \\
GG & $34(0.147)$ & $18(0.132)$ \\
Alleles & & \\
A & $302(0.654)$ & $172(0.632)$ \\
G & $160(0.346)$ & $100(0.368)$ \\
\hline
\end{tabular}

Genotype and allele frequencies are expressed in brackets. Both groups were in Hardy-Weinberg equilibrium. Allele A showed an Odds Ratio of 1.097 (SE 0.159, Confidence Intervals 0.803-1.500) and a Relative Risk of 1.034 (SE 0.057, Confidence Intervals 0.924-1.137).

\section{No AD genetic risk associated with the TPI gene}

Considering that TPI deficiencies have been associated with pathological neurologic symptoms [19, 21] we analyzed the possible existence of TPI polymorphisms associated with AD (Table 1). As TPI is a small gene ( $\sim 3$ kilobases) located in a region with an estimated recombination rate of $3.0 \mathrm{cM} / \mathrm{Mb}$, the genotyping of a single SNP would cover its genetic diversity. Our analysis did not disclose any significant differences in genotypes $\left(\chi^{2}=1.839, p=0.399\right)$ or allelic frequencies $\left(\chi^{2}=0.794, p=0.373\right)$ between cases and controls. These data support that TPI is a highly conserved protein due to its key role in glycolysis and any change is discarded rapidly due to its deleterious effects.

\section{DISCUSSION}

Tyrosine nitration, an irreversible post-translational modification, is increased in $\mathrm{AD}[11,12]$ and the glycolytic TPI enzyme is one of the most nitrotyrosinated proteins in this disease [16, 26, 27]. TPI nitrotyrosination has a major consequence: it reduces glycolytic flow, which triggers production of $\mathrm{MG}$, a compound associated with AD [16]. MG is produced by the formation of big protein aggregates due to cross-linking and by the decomposition of DHAP; its toxicity results from its ability to irreversibly modify proteins, lipids, and nucleic acids [40] (Supplementary Figure 10).

The TPI monomer has four tyrosines. The first two-Tyr47 and Tyr67-remain at the interface of the dimer in opposite orientations, thus tyrosines from different monomers do not face each other, whereas the remaining two-Tyr165 and Tyr209-interact directly, sit very close to the catalytic site, and con- tribute to loop 6 mobility. Loop 6 is very flexible and plays a key role in the reactivity of the enzyme [39]. We selected Tyr165 and Tyr209 for study because of their importance to enzyme efficiency and their role in MG generation. Our proteomic analysis showed that both tyrosines were nitrated when exposed to peroxynitrite.

In the present work, a combination of short classical MD simulations and QM/MM calculations helped us to predict the consequences of the nitrative modification in loop 6 of the TPI. We present a model showing how TPI nitrotyrosination at Tyr165 and Tyr209 would destabilize the closed state of the loop, affecting enzyme efficiency and promoting MG production. We also demonstrated that Tyr165Phe and Tyr209Phe mutations mimic the effect of nitrotyrosination on loop stability. Both situations were associated with increased production of the toxic compound, MG, which has the ability to irreversibly modify proteins, lipids, and nucleic acids.

When TPI efficiency is reduced, the substrate DHAP accumulates and is associated with increased MG production and, consequently, with protein glycation. It has been reported that MG rapidly glycates proteins, damages mitochondria, and induces a pro-oxidant state similar to that observed in aged cells [41]. This harmful scenario was present in the AD brain tissue [42] and high MG levels have been found in cerebrospinal fluid of patients affected by AD [43]. Glycation also has been associated with apoptosis $[22,23]$, a pathologic process widely reported in $\mathrm{AD}$ [44]. Moreover, MG cytotoxicity has been associated with the impairment of cognitive function in diabetes [45].

We found TPI nitrotyrosination in AD patient cortex and in human neuroblastoma cells treated with $A \beta$ oligomers. These findings were correlated with high protein glycation in AD patient cortex, in the hippocampus of double transgenic mice overexpressing $\mathrm{A} \beta \mathrm{PP}$ and PS1, and in human neuroblastoma cells treated with $A \beta$ oligomers. These data suggest that TPI nitrotyrosination is playing a key role in the neurodegeneration triggered by $A \beta$. Cell viability declined consistently in human neuroblastoma cells transfected with the double-mutant TPI, which mimics the molecular effects of TPI nitrotyrosination. These results confirm existing evidence that apoptosis is the underlying mechanism for the neurodegeneration caused by TPI nitrotyrosination, reported in $\mathrm{AD}[44,46]$ and in $\mathrm{A} \beta$-induced nitro-oxidative stress [38, 47]. Mitochondria plays an essential role in cell death because the permeability of the transition pore and the collapse of 
$\Delta \Psi_{\mathrm{m}}$ are the initial stages in intracellular apoptotic signaling [34]. Consistently we obtained a loss of $\Delta \Psi_{\mathrm{m}}$ in TPI double-mutant cells, which was associated with an increase in Bax, a classical pro-apoptotic protein previously reported to be enhanced in $\mathrm{AD}$ [23]. We observed that $\mathrm{A} \beta$ oligomers and double-mutant TPI increased MG production by abnormal TPI function. Furthermore, we demonstrated that the increase of MG is related with the toxicity induced by $A \beta$, resulting in increased levels of the active pro-apoptotic caspase-3. Caspase- 3 is critical in apoptosis onset and a recent study links it to enhanced synaptic failure in an $\mathrm{AD}$ mouse model [48], which is a very early event in the disease onset. All these effects were reverted when cells were incubated with a MG scavenger, supporting evidence that $\mathrm{MG}$ is one of the most important intracellular mediators of $\mathrm{A} \beta$-induced apoptosis. However, we cannot discard that other mechanisms are contributing to $A \beta$ neurodegeneration.

On the other hand, once the MG burst is triggered there is a plethora of targets that could be glycated including proteins, lipids, and nucleic acids [40]. One of the most relevant proteins for $\mathrm{AD}$ that can be glycated is tau, whose glycation has been proposed to favor its hyperphosphorylation and aggregation into neurofibrillary tangles [49-52]. Altogether this contributes to the characteristic neuronal damage of $\mathrm{AD}$.

Finally, we analyzed the possibility that some polymorphisms in the TPI gene [53] could be associated with $\mathrm{AD}$. Although its mutations correlate with neurological dysfunction, we observed no association between $\mathrm{AD}$ and the TPI gene, reinforcing the importance of post-translational modifications such as nitrotyrosination in the gene's observed relationship with $\mathrm{AD}$ onset and progression.

In conclusion, we have obtained the first results suggesting that $A \beta$ oligomers induce neuronal death by triggering $\mathrm{MG}$ production. Increased release of $\mathrm{MG}$ is a direct consequence of TPI nitrotyrosination due to $A \beta$ action at the two tyrosines located in the catalytic center of the gene. MG leads to neuronal death by activating pro-apoptotic intracellular signaling. This finding links $\mathrm{A} \beta$ with neurodegeneration.

\section{ACKNOWLEDGMENTS}

We thank Dr. Tadashi Nakaya and Dr. David Comas for their technical support. The authors acknowledge the computer resources, technical expertise, and assistance provided by the Barcelona
Supercomputing Center - Centro Nacional de Supercomputación. We also wish to acknowledge the Banc de Teixits Neurològics, Serveis Cientifico-Tècnics, Hospital Clínic, Universitat de Barcelona for providing the brain samples. This work was supported by the Spanish Ministry of Science and Innovation (SAF2010-16725; Fondo de Investigación Sanitaria PI10/00587 and PI10/01076; Red HERACLES RD12/0042/0014- FEDER Funds; CTQ2008-00755; BFU2006-28430-E/BMC and RETIC COMBIOMED RD07/0067/0001); the virtual physiological human (VPH) NoE (FP7-ICT-2007-2-223920); Generalitat de Catalunya (AGAUR BE-2 10240; SGR2009-1369); and La Marató de TV3 (No 100310 and 100610).

Authors' disclosures available online (http://www. j-alz.com/disclosures/view.php?id=2119).

\section{SUPPLEMENTARY MATERIAL}

Supplementary figures are available in the electronic version of this article: http://dx.doi.org/10.3233/JAD131685 .

\section{REFERENCES}

[1] Huang X, Cuajungco MP, Atwood CS, Hartshorn MA, Tyndall JD, Hanson GR, Stokes KC, Leopold M, Multhaup G, Goldstein LE, Scarpa RC, Saunders AJ, Lim J, Moir RD, Glabe C, Bowden EF, Masters CL, Fairlie DP, Tanzi RE, Bush AI (1999) Cu(II) potentiation of Alzheimer Abeta neurotoxicity. Correlation with cell-free hydrogen peroxide production and metal reduction. J Biol Chem 274, 37111-37116.

[2] Huang X, Atwood CS, Hartshorn MA, Multhaup G, Goldstein LE, Scarpa RC, Cuajungco MP, Gray DN, Lim J, Moir RD, Tanzi RE, Bush AI (1999) The A beta peptide of Alzheimer's disease directly produces hydrogen peroxide through metal ion reduction. Biochemistry 38, 7609-7616.

[3] Varadarajan S, Yatin S, Kanski J, Jahanshahi F, Butterfield DA (1999) Methionine residue 35 is important in amyloid betapeptide-associated free radical oxidative stress. Brain Res Bull 50, 133-141.

[4] Mattson MP (2004) Pathways towards and away from Alzheimer's disease. Nature 430, 631-639.

[5] Yu JT, Chang RC, Tan L (2009) Calcium dysregulation in Alzheimer's disease: From mechanisms to therapeutic opportunities. Prog Neurobiol 89, 240-255.

[6] Bredt DS, Snyder SH (1994) Nitric oxide: A physiologic messenger molecule. Annu Rev Biochem 63, 175-195.

[7] Moncada S, Palmer RM, Higgs EA (1991) Nitric oxide: Physiology, pathophysiology, and pharmacology 59. Pharmacol Rev 43, 109-142.

[8] Beckman JS, Beckman TW, Chen J, Marshall PA, Freeman BA (1990) Apparent hydroxyl radical production by peroxynitrite: Implications for endothelial injury from nitric oxide and superoxide. Proc Natl Acad Sci U S A 87, 1620-1624.

[9] Brennan ML, Wu W, Fu X, Shen Z, Song W, Frost H, Vadseth C, Narine L, Lenkiewicz E, Borchers MT, Lusis AJ, Lee JJ, Lee NA, bu-Soud HM, Ischiropoulos H, Hazen SL (2002) A 
tale of two controversies: Defining both the role of peroxidases in nitrotyrosine formation in vivo using eosinophil peroxidase and myeloperoxidase-deficient mice, and the nature of peroxidase-generated reactive nitrogen species. $J$ Biol Chem 277, 17415-17427.

[10] Souza JM, Daikhin E, Yudkoff M, Raman CS, Ischiropoulos H (1999) Factors determining the selectivity of protein tyrosine nitration. Arch Biochem Biophys 371, 169-178.

[11] Smith MA, Richey Harris PL, Sayre LM, Beckman JS, Perry G (1997) Widespread peroxynitrite-mediated damage in Alzheimer's disease. J Neurosci 17, 2653-2657.

[12] Hensley K, Maidt ML, Yu Z, Sang H, Markesbery WR, Floyd RA (1998) Electrochemical analysis of protein nitrotyrosine and dityrosine in the Alzheimer brain indicates region-specific accumulation. J Neurosci 18, 8126-8132.

[13] Quintanilla RA, Munoz FJ, Metcalfe MJ, Hitschfeld M, Olivares G, Godoy JA, Inestrosa NC (2005) Trolox and 17beta-estradiol protect against amyloid beta-peptide neurotoxicity by a mechanism that involves modulation of the Wnt signaling pathway. J Biol Chem 280, 11615-11625.

[14] Huang TC, Lu KT, Wo YY, Wu YJ, Yang YL (2011) Resveratrol protects rats from Abeta-induced neurotoxicity by the reduction of iNOS expression and lipid peroxidation. PLOS One 6, e2910

[15] Coma M, Guix FX, Uribesalgo I, Espuna G, Sole M, Andreu D, Munoz FJ (2005) Lack of oestrogen protection in amyloidmediated endothelial damage due to protein nitrotyrosination. Brain 128, 1613-1621.

[16] Guix FX, Ill-Raga G, Bravo R, Nakaya T, de FG, Coma, Miscione GP, Villa-Freixa J, Suzuki T, Fernandez-Busquets X, Valverde MA, de SB, Munoz FJ (2009) Amyloid-dependent triosephosphate isomerase nitrotyrosination induces glycation and tau fibrillation. Brain 132, 1335-1345.

[17] Richard JP (1993) Mechanism for the formation of methylglyoxal from triosephosphates. Biochem Soc Trans 21, 549-553.

[18] Hoyer S (1996) Oxidative metabolism deficiencies in brains of patients with Alzheimer's disease. Acta Neurol Scand Suppl 165, 18-24.

[19] Olah J, Orosz F, Puskas LG, Hackler L Jr, Horanyi M, Polgar L, Hollan S, Ovadi J (2005) Triosephosphate isomerase deficiency: Consequences of an inherited mutation at mRNA, protein and metabolic levels. Biochem J 392, 675-683.

[20] Seigle JL, Celotto AM, Palladino MJ (2008) Degradation of functional triose phosphate isomerase protein underlies sugarkill pathology. Genetics 179, 855-862.

[21] Orosz F, Olah J, Ovadi J (2009) Triosephosphate isomerase deficiency: New insights into an enigmatic disease. Biochim Biophys Acta 1792, 1168-1174.

[22] Kikuchi S, Shinpo K, Moriwaka F, Makita Z, Miyata T, Tashiro K (1999) Neurotoxicity of methylglyoxal and 3deoxyglucosone on cultured cortical neurons: Synergism between glycation and oxidative stress, possibly involved in neurodegenerative diseases. J Neurosci Res 57, 280-289.

[23] Okouchi M, Okayama N, Aw TY (2005) Differential susceptibility of naive and differentiated PC-12 cells to methylglyoxal-induced apoptosis: Influence of cellular redox. Curr Neurovasc Res 2, 13-22.

[24] Yan SD, Yan SF, Chen X, Fu J, Chen M, Kuppusamy P, Smith MA, Perry G, Godman GC, Nawroth P, Zweier JL, Stern D (1995) Non-enzymatically glycated tau in Alzheimer's disease induces neuronal oxidant stress resulting in cytokine gene expression and release of amyloid beta-peptide. Nat Med $\mathbf{1}$, 693-699.

[25] Stadtman ER (2001) Protein oxidation in aging and agerelated diseases. Ann NY Acad Sci 928, 22-38.
[26] Butterfield DA, Perluigi M, Sultana R (2006) Oxidative stress in Alzheimer's disease brain: New insights from redox proteomics. Eur J Pharmacol 545, 39-50.

[27] Butterfield DA, Reed TT, Perluigi M, De MC, Coccia R, Keller JN, Markesbery WR, Sultana R (2007) Elevated levels of 3-nitrotyrosine in brain from subjects with amnestic mild cognitive impairment: Implications for the role of nitration in the progression of Alzheimer's disease. Brain Res 1148, 243-248.

[28] Rappsilber J, Mann M, Ishihama Y (2007) Protocol for micro-purification, enrichment, pre-fractionation and storage of peptides for proteomics using StageTips. Nat Protoc 2, 1896-1906.

[29] McKhann G, Drachman D, Folstein M, Katzman R, Price D, Stadlan EM (1984) Clinical diagnosis of Alzheimer's disease: Report of the NINCDS-ADRDA Work Group under the auspices of Department of Health and Human Services Task Force on Alzheimer's Disease. Neurology 34, 939-944.

[30] Castegna A, Thongboonkerd V, Klein JB, Lynn B, Markesbery WR, Butterfield DA (2003) Proteomic identification of nitrated proteins in Alzheimer's disease brain. J Neurochem 85, 1394-1401.

[31] Mukohda M, Okada M, Hara Y, Yamawaki H (2012) Exploring mechanisms of diabetes-related macrovascular complications: Role of methylglyoxal, a metabolite of glucose on regulation of vascular contractility. J Pharmacol Sci 118, 303-310.

[32] Fodero-Tavoletti MT, Villemagne VL, Rowe CC, Masters CL, Barnham KJ, Cappai R (2011) Amyloid- $\beta$ : The seeds of darkness. Int J Biochem Cell Biol 43, 1247-1251.

[33] Huang SM, Chuang HC, Wu CH, Yen GC (2008) Cytoprotective effects of phenolic acids on methylglyoxal-induced apoptosis in Neuro-2A cells. Mol Nutr Food Res 52, 940-949.

[34] Bader Lange ML, St CD, Markesbery WR, Studzinski CM, Murphy MP, Butterfield DA (2010) Age-related loss of phospholipid asymmetry in APP(NLh)/APP(NLh) x PS1(P264L)/PS-1(P264L) human double mutant knock-in mice: Relevance to Alzheimer disease. Neurobiol Dis 38, 104-115.

[35] Jarero-Basulto JJ, Luna-Muñoz J, Mena R, Kristofikova Z, Ripova D, Perry G, Binder LI, Garcia-Sierra F (2013) Proteolytic cleavage of polymeric tau protein by caspase-3: Implications for Alzheimer disease. J Neuropathol Exp Neurol 72, 1145-1161.

[36] Dhar A, Dhar I, Desai KM, Wu L (2010) Methylglyoxal scavengers attenuate endothelial dysfunction induced by methylglyoxal and high concentrations of glucose. Br J Pharmacol 161, 1843-1856.

[37] de Arriba SG, Krugel U, Regenthal R, Vissiennon Z, Verdaguer E, Lewerenz A, Garcia-Jorda E, Pallas M, Camins A, Munch G, Nieber K, Allgaier C (2006) Carbonyl stress and NMDA receptor activation contribute to methylglyoxal neurotoxicity. Free Radic Biol Med 40, 779-790.

[38] Alvarez B, Radi R (2003) Peroxynitrite reactivity with amino acids and proteins. Amino Acids 25, 295-311.

[39] Alber T, Banner DW, Bloomer AC, Petsko GA, Phillips D, Rivers PS, Wilson IA (1981) On the three-dimensional structure and catalytic mechanism of triose phosphate isomerase. Philos Trans R Soc Lond B Biol Sci 293, 159-171.

[40] Scheckhuber CQ, Mack SJ, Strobel I, Ricciardi F, Gispert S, Osiewacz HD (2010) Modulation of the glyoxalase system in the aging model Podospora anserina: Effects on growth and lifespan. Aging 2, 969-980.

[41] Hipkiss AR (2006) On the mechanisms of ageing suppression by dietary restriction-is persistent glycolysis the problem? Mech Ageing Dev 127, 8-15. 
[42] Caldeira GL, Ferreira IL, Rego AC (2013) Impaired transcription in Alzheimer's disease: Key role in mitochondrial dysfunction and oxidative stress. J Alzheimers Dis 34, 115131.

[43] Rahmadi A, Steiner N, Münch G (2011) Advanced glycation endproducts as gerontotoxins and biomarkers for carbonylbased degenerative processes in Alzheimer's disease. Clin Chem Lab Med 49, 385-391.

[44] Su JH, Anderson AJ, Cummings BJ, Cotman CW (1994) Immunohistochemical evidence for apoptosis in Alzheimer's disease. Neuroreport 5, 2529-2533.

[45] Chen YJ, Huang XB, Li ZX, Yin LL, Chen WQ, Li L (2010) Tenuigenin protects cultured hippocampal neurons against methylglyoxal-induced neurotoxicity. Eur J Pharmacol 645, 1-8.

[46] LaFerla FM, Tinkle BT, Bieberich CJ, Haudenschild CC, Jay $\mathrm{G}$ (1995) The Alzheimer's Abeta peptide induces neurodegeneration and apoptotic cell death in transgenic mice. Nat Genet 9, 21-30.

[47] Ill-Raga G, Ramos-Fernandez E, Guix FX, Tajes M, BoschMorato M, Palomer E, Godoy J, Belmar S, Cerpa W, Simpkins JW, Inestrosa NC, Munoz FJ (2010) Amyloid-beta peptide fibrils induce nitro-oxidative stress in neuronal cells. J Alzheimers Dis 22, 641-652.
[48] D'Amelio M, Cavallucci V, Middei S, Marchetti C, Pacioni S, Ferri A, Diamantini A, De ZD, Carrara P, Battistini L, Moreno S, Bacci A, mmassari-Teule M, Marie H, Cecconi F (2011) Caspase-3 triggers early synaptic dysfunction in a mouse model of Alzheimer's disease. Nat Neurosci 14, 69-76.

[49] Li XH, Lv BL, Xie JZ, Liu J, Zhou XW, Wang JZ (2012) AGEs induce Alzheimer-like tau pathology and memory deficit via RAGE-mediated GSK-3 activation. Neurobiol Aging 33, 1400-1410.

[50] Kuhla B, Haase C, Flach K, Lüth HJ, Arendt T, Münch G (2007) Effect of pseudophosphorylation and cross-linking by lipid peroxidation and advanced glycation end product precursors on tau aggregation and filament formation. $J$ Biol Chem 282, 6984-6991.

[51] Ledesma MD, Medina M, Avila J (1996) The in vitro formation of recombinant tau polymers: Effect of phosphorylation and glycation. Mol Chem Neuropathol 27, 249-258.

[52] Ledesma MD, Bonay P, Avila J (1995) Tau protein from Alzheimer's disease patients is glycated at its tubulin-binding domain. J Neurochem 65, 1658-1664.

[53] Orosz F, Olah J, Ovadi J (2006) Triosephosphate isomerase deficiency: Facts and doubts. IUBMB Life 58, 703-715. 


\section{SUPPLEMENTARY DATA}

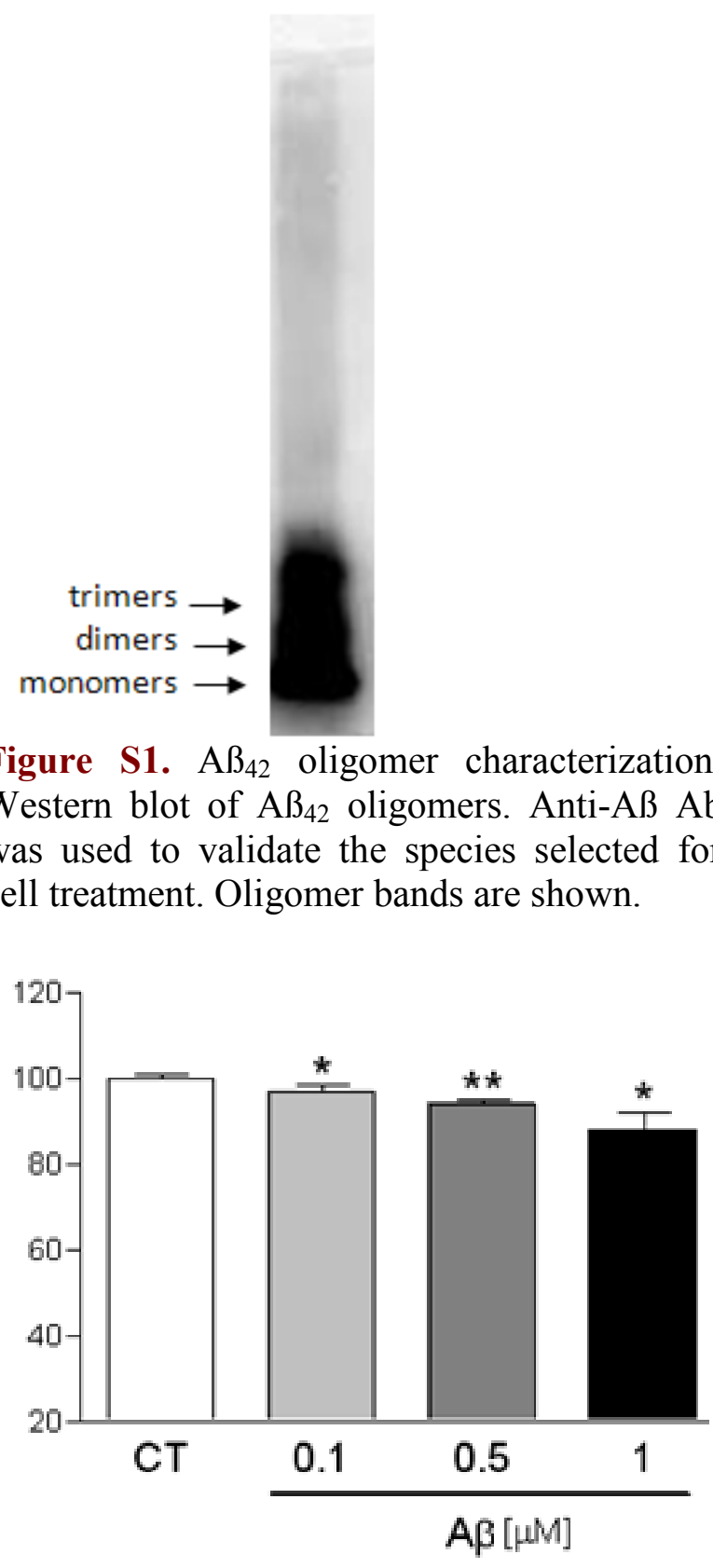

Figure S2. Glucose uptake in neuroblastoma cells. Glucose uptake in cells treated with increasing concentrations of $\mathrm{A} \beta$ oligomers. Glucose uptake was quantified and expressed as (AU). Data are mean \pm SEM of 4 independent experiments. ${ }^{*} \mathrm{p}<0.05, * * \mathrm{p}<0.01 v s$ control by Student $\mathrm{t}$ test.

\section{A}

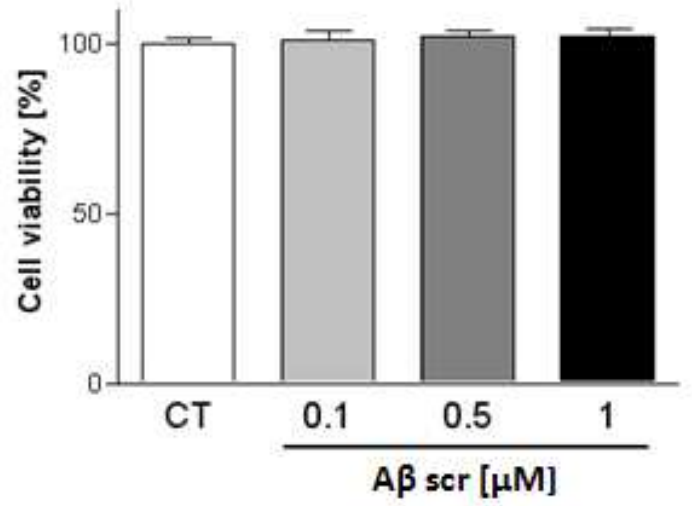

B
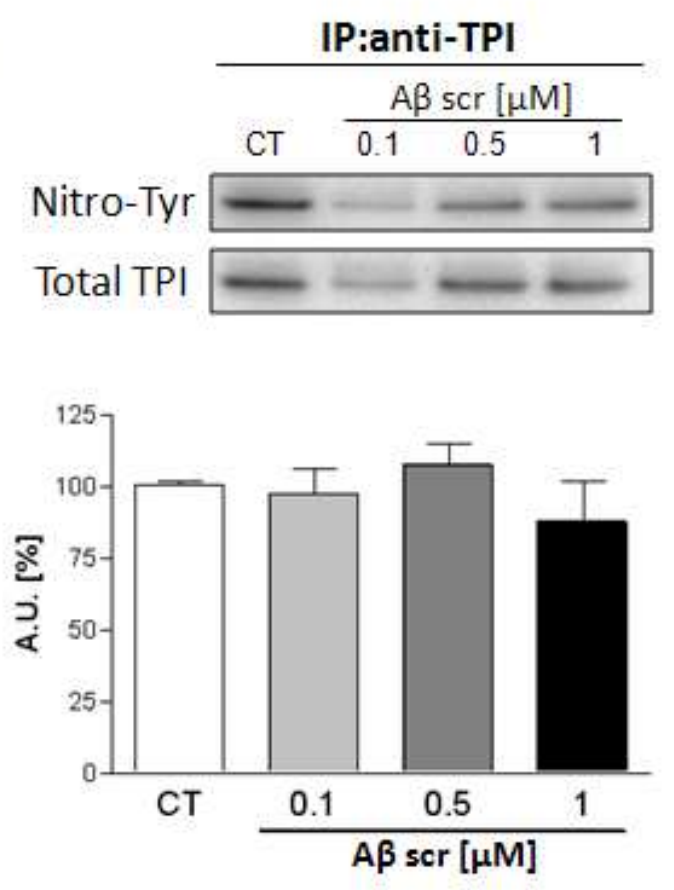

Figure S3. The scrambled $A \beta_{42}$ cannot induce the nitrotyrosination of TPI. (A) Neuroblastoma cells were challenged with increasing concentrations of scrambled $\mathrm{A} \beta_{42}$ for $24 \mathrm{~h}$. Cell viability was assayed by MTT reduction. Data are mean \pm SEM of 3 independent experiments performed in triplicate. (B) Western blot of immunoprecipitated TPI from neuroblastoma cells treated with increasing concentrations of scrambled $A \beta_{42}$ for $24 \mathrm{~h}$. Blots were performed with anti-nitrotyrosine and anti-TPI Abs. Data are mean \pm SEM of 3 independent experiments 
A

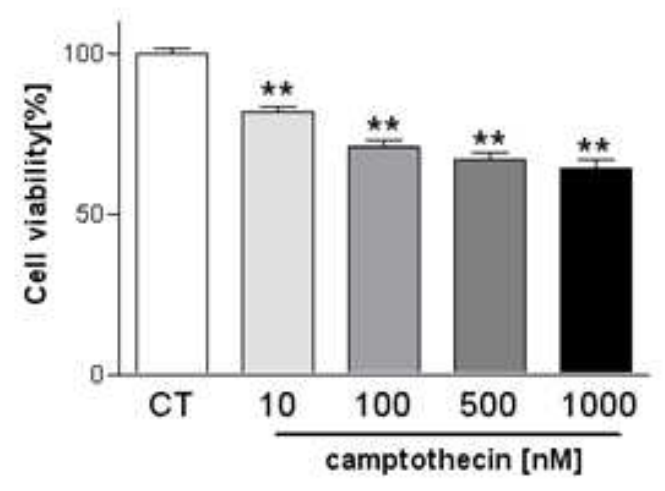

B

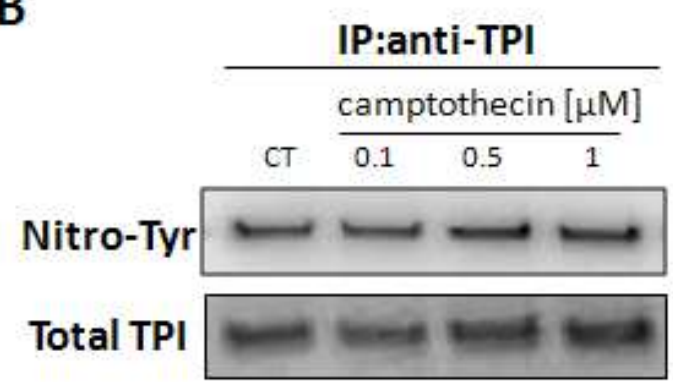

C

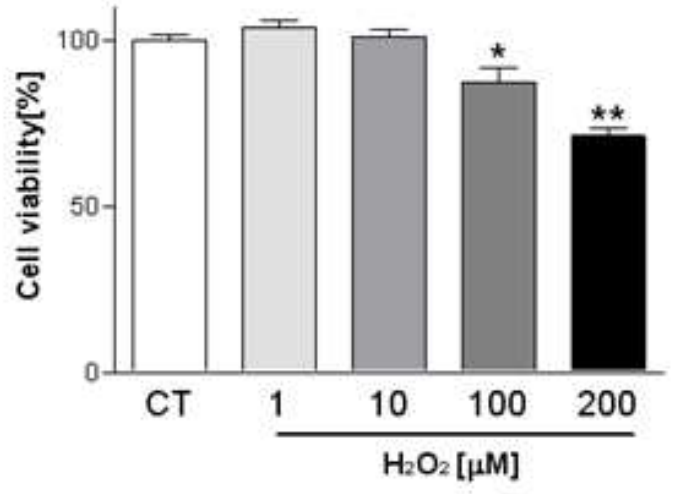

D

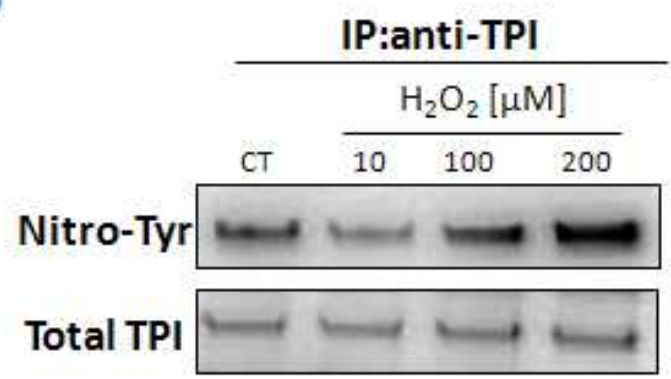

Figure S4. Nitrotyrosination of TPI is due to nitro-oxidative stress. (A) Neuroblastoma cells were challenged with increasing concentrations of camptothecin, a proapoptotic compound, and $\mathrm{H}_{2} \mathrm{O}_{2}$, a pro-oxidant compound, for $24 \mathrm{~h}$. Cell viability was assayed by MTT reduction. Data are mean $\pm \mathrm{SEM}$ of 3 independent experiments performed in triplicate. ${ }^{*} \mathrm{p}<0.05$, ${ }^{* *} \mathrm{p}<0.001$ by Student $\mathrm{t}$ test. (B) Western blot of immunoprecipitated TPI from neuroblastoma cells treated with increasing concentrations of camptothecin and $\mathrm{H}_{2} \mathrm{O}_{2}$ for $24 \mathrm{~h}$. Blots were performed with anti-nitrotyrosine and anti-TPI Abs.

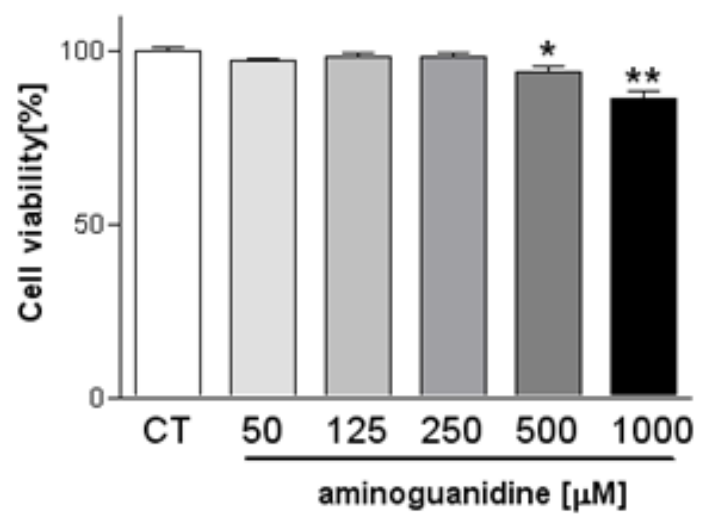

Figure S5. Aminoguanidine dose-response curve. Neuroblastoma cells were treated with increasing concentrations of AG. Cell viability was assayed by MTT reduction. Data are mean \pm SEM of 3 independent experiments performed in triplicate. ${ }^{*} \mathrm{p}<0.01,{ }^{* *} \mathrm{p}<0.001 \mathrm{vs}$ control by Student $\mathrm{t}$ test. 


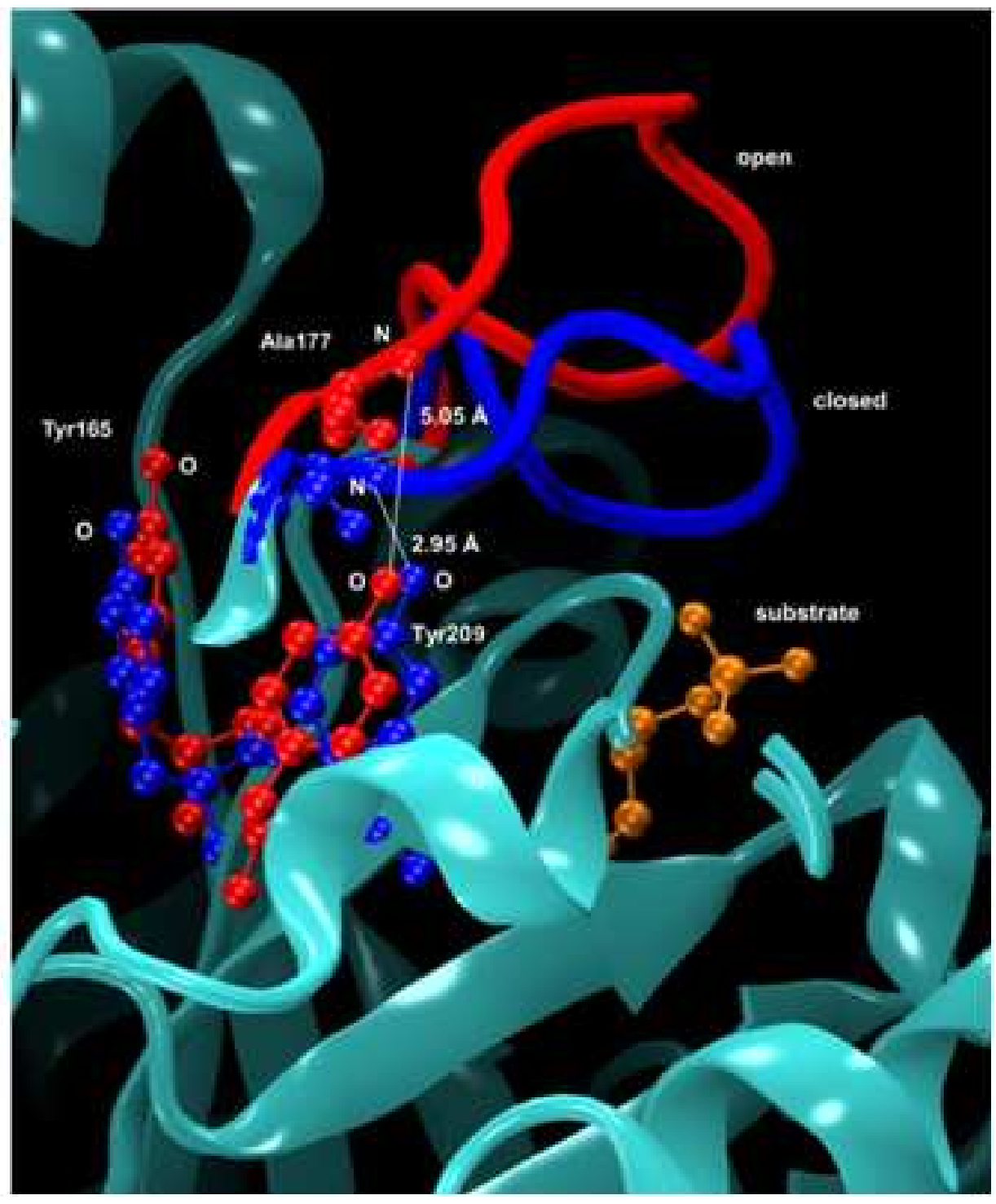

Figure S6. Loop 6 conformational changes in TPI. Image of the loop in the open/closed state showing the distances between the amidic nitrogen $\mathrm{NH}$ of Ala176 and the On oxygen of Tyr209 in both states. 


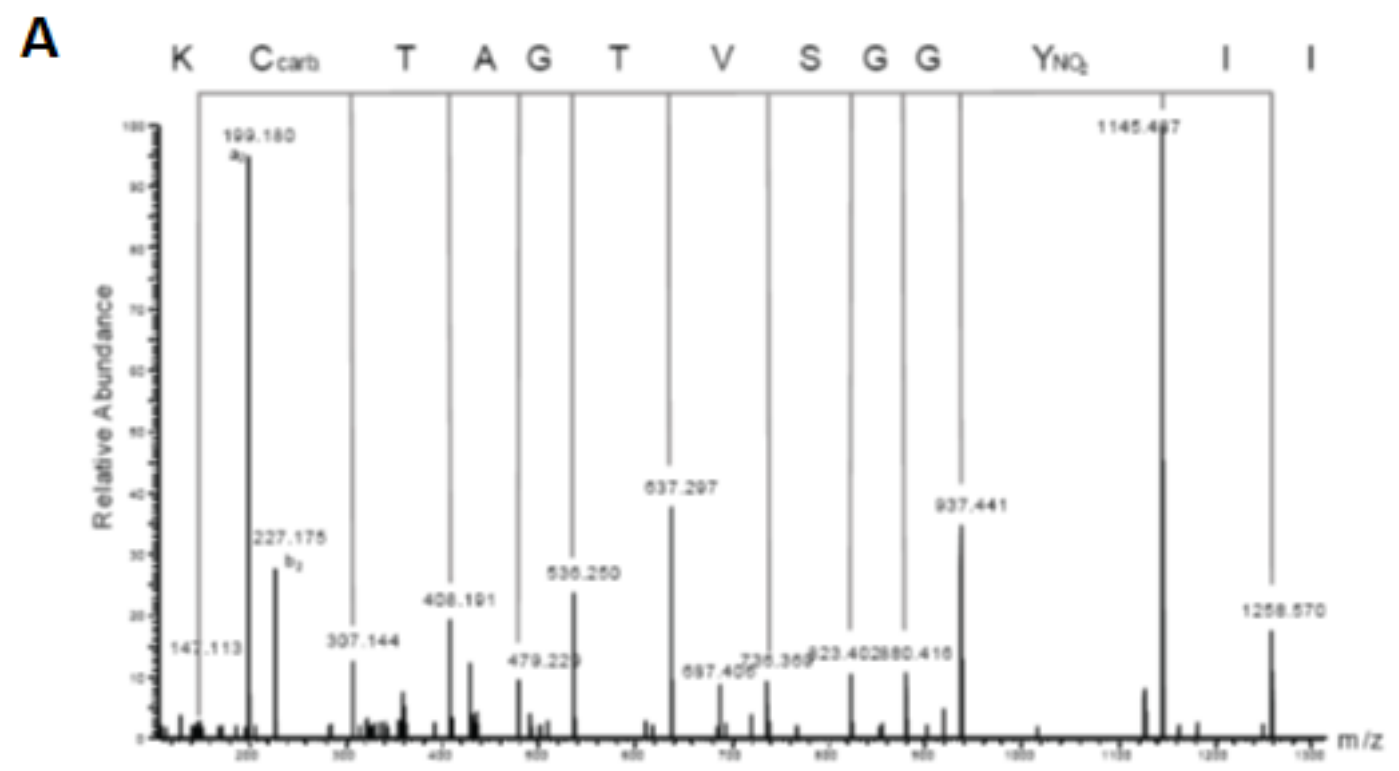

B

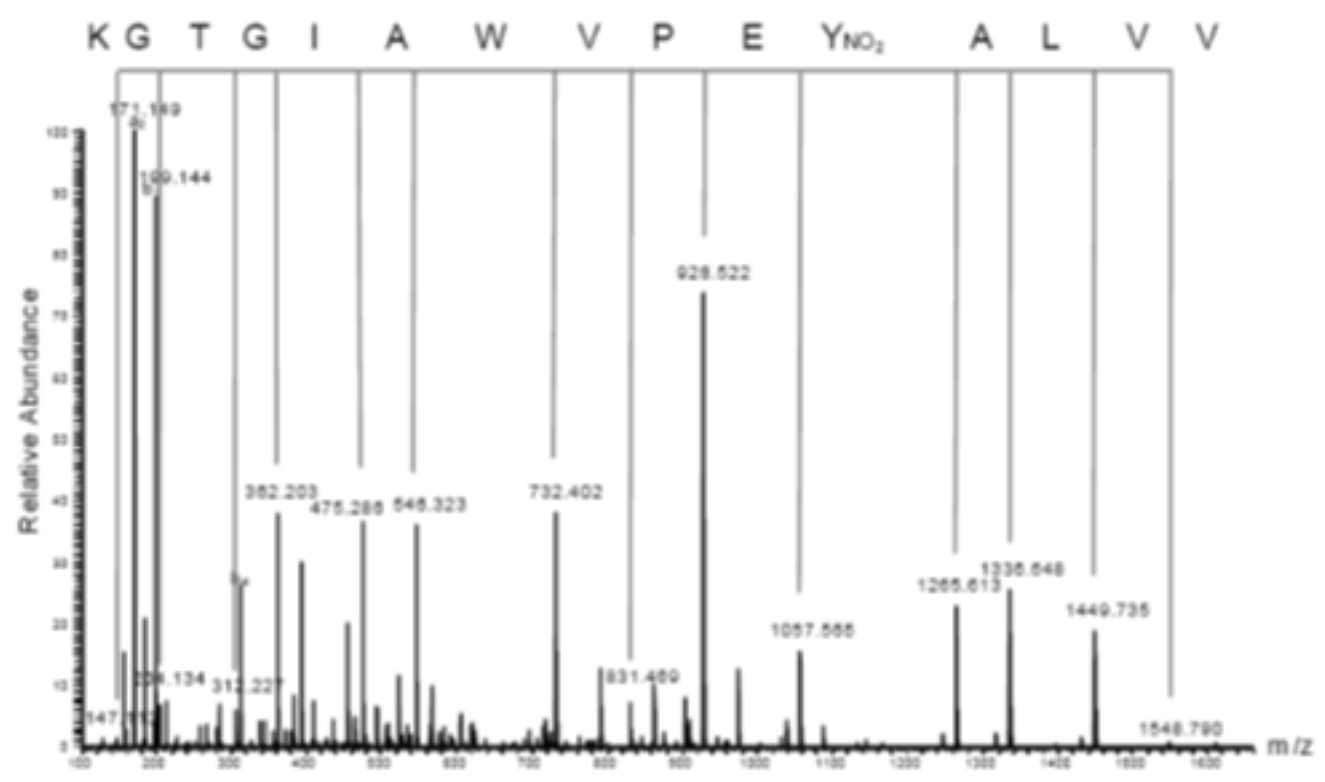

Figure S7. Proteomic analysis of TPI nitrotyrosination. TPI was treated in vitro with SIN-1 as indicated in the Material and Methods section. Annotated tandem MS (HCD) spectra of two tryptic tyrosine nitrosylated peptides originating from TPI are shown: (A) IIY(NO2)GGSVTGATCK and (B) VVLAY(NO2)EPVWAIGTGK. In the spectra, vertical lines indicate $y$-ions used for the manual validation of the peptide sequences. Deduced peptide sequences (from $\mathrm{C}$-terminal to $\mathrm{N}$-terminal) are inserted above each spectrum. $\mathrm{Y}\left(\mathrm{NO}_{2}\right)$ indicate a nitrosylated tyrosine residue. Additional a- and b-ions are marked. 

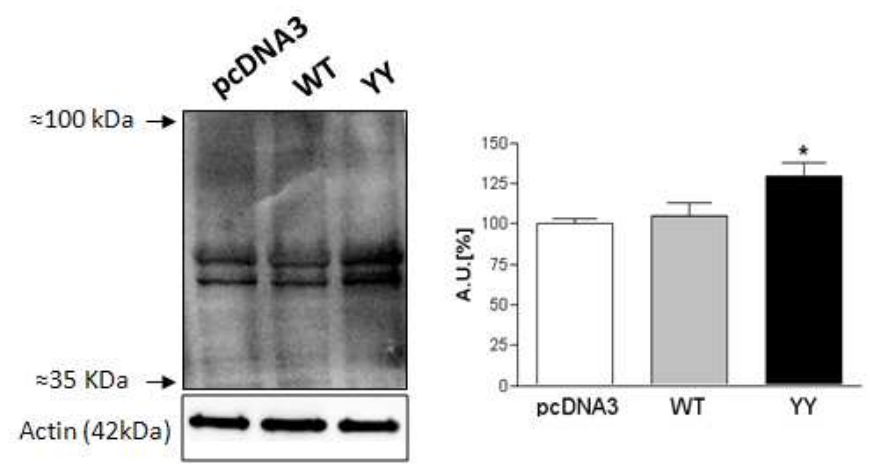

Figure S8. Increased protein glycation in cells o.e. YY TPI. Cells o.e. the double mutant TPI Y165F/Y209F were lysed and the total protein was analyzed by Western blot using an anti-argpyrimidine Ab. Glycation was quantified and expressed as (AU). Data are mean \pm SEM of 3 independent experiments. ${ }^{*} \mathrm{p}<0.05$ vs controls by Student $\mathrm{t}$ test. 
A
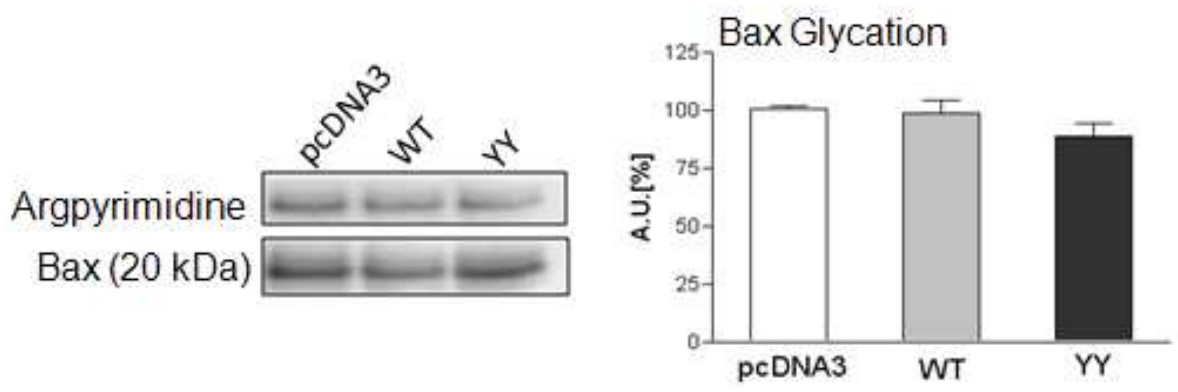

B
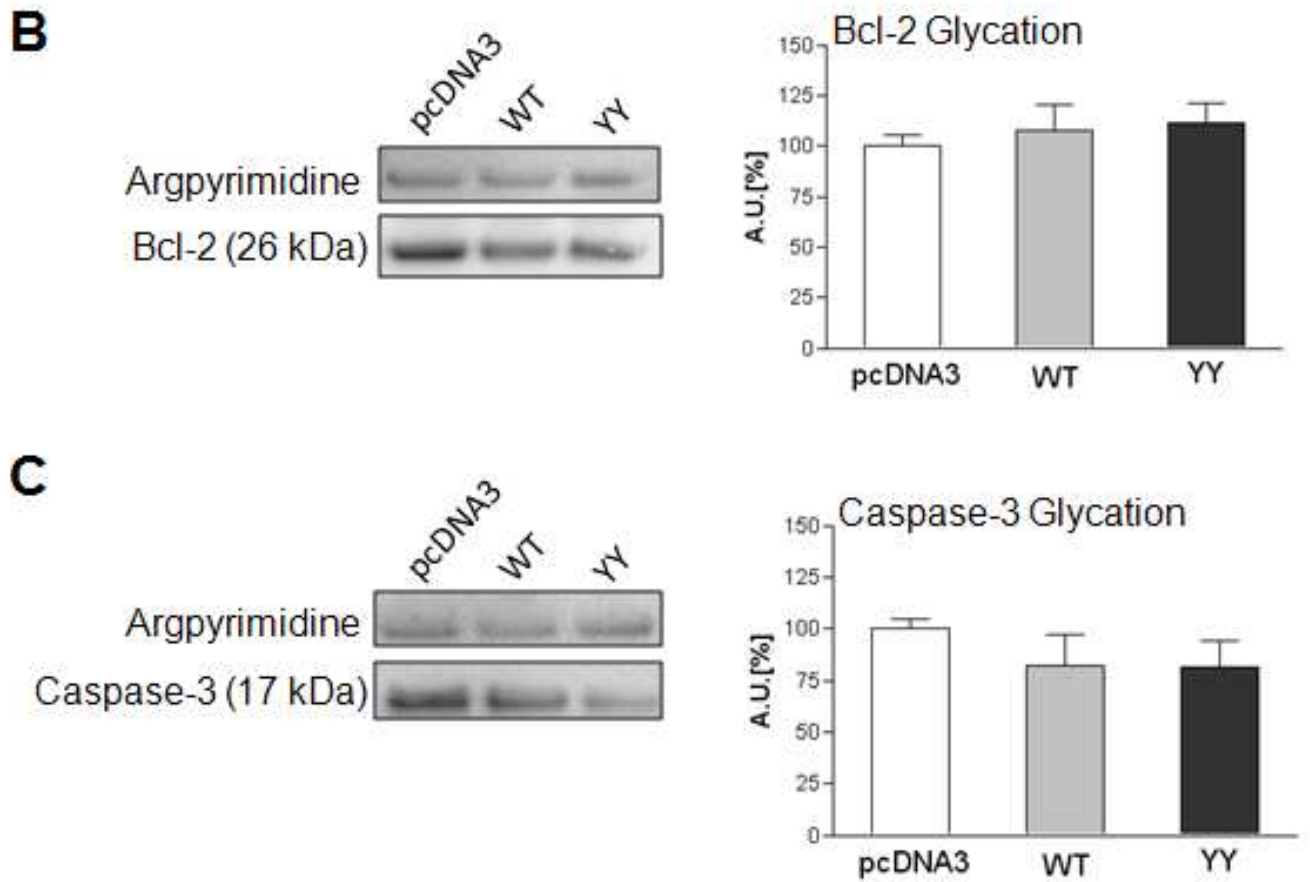

Figure S9. Lack of glycation in apoptotic proteins from cells o.e. double-mutant TPI Y165F/Y209F. Western blot analysis of Bax (A), Bcl-2 (B) and caspase-3 (C) levels in cells o.e. pcDNA3, WT TPI or YY TPI. Blots were performed with anti-argpyrimidine and anti-Bax (A), anti-Bcl-2 (B) or anti-caspase-3 (C) Abs. Quantifications expressed as arbitrary units (AU) are shown in the graphs. Data are mean \pm SEM of 3 independent experiments. 
A

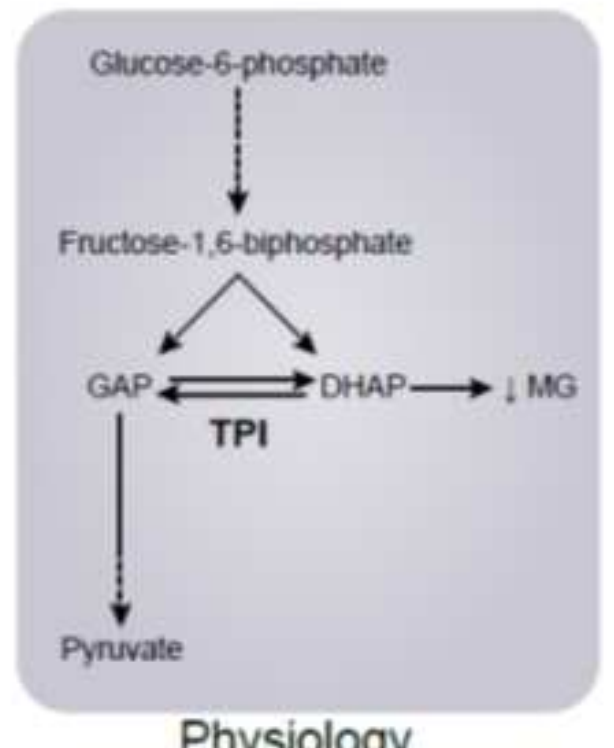

B

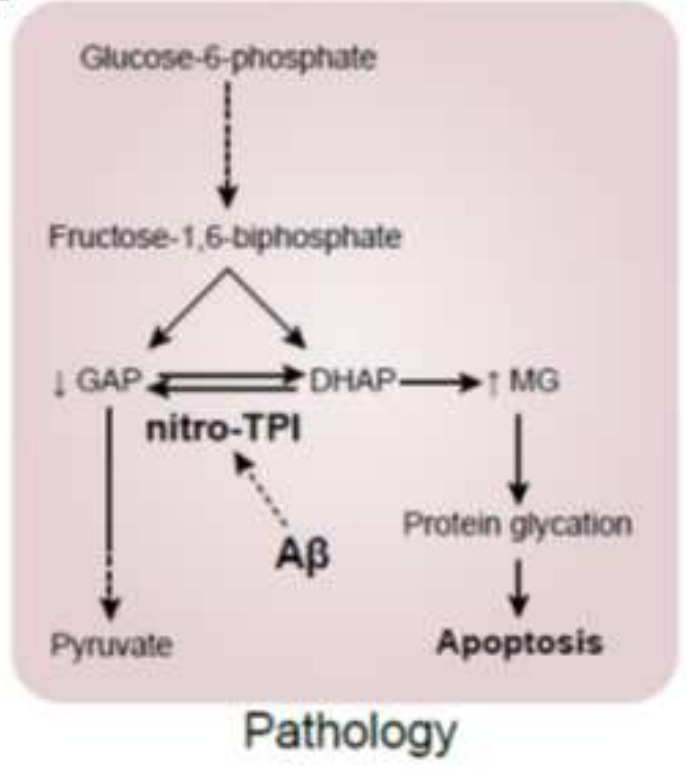

Figure S10. TPI activity in physiological and pathological states. (A) Under physiological conditions MG production by the non-enzymatic decomposition of DHAP is very low, and the correct function of TPI allows the continuity of the glycolysis pathway. (B) Under pathological conditions, A $\beta$ induces TPI nitrotyrosination. This posttranslational modification diminishes its efficiency and increases the production of the toxic by-product MG, which leads to neuronal apoptosis. 